\title{
Chapter 19 \\ Demographic Changes, Trade Routes, and the Formation of Anthropogenic Landscapes in the Middle Volga Region in the Past 2500 Years
}

\author{
Leonid A. Vyazov, Ekaterina G. Ershova, Elena V. Ponomarenko, \\ Konrad Gajewski, Mikhail S. Blinnikov and Ayrat G. Sitdikov
}

\begin{abstract}
The development of landscapes of the central part of the Middle-Volga region in the last 2500 years was a discontinuous process of the explosive growth of population and land utilization alternating with stages of depopulation and desolation. The periods of depopulation and transitions of cultures occurred at similar times to climate changes. Some cultures were associated with distinct climatic episodes, such as the association of the Dark Ages Cold Period with Hun, post Hun, Heraldic, and Khasarian times, and the Medival Warm Period with the time of Volga Bulgaria. A combination of archaeological and paleoecological analyses allowed us to reconstruct a sequence of landscape and land use changes in relation to the historical development of the region. The first millennium $\mathrm{CE}$ was a time of major changes in population, agricultural technologies, social structure, and settlement patterns in the forest-steppe zone. The MiddleVolga region underwent a transition from a non-populated, mainlyforested landscape of first centuries $\mathrm{CE}$ to a highly deforested agricultural landscape of the Volga Bulgarian state by the 11th century CE. Within several centuries, the landscape was transformed by shifting cultivation, wood and ore extraction, and the formation and expansion of pastures and road networks. The process of deforestation in the region was facilitated by the relatively warm climates of the Medieval Warm Period.
\end{abstract}

L. A. Vyazov · E. G. Ershova · E. V. Ponomarenko $(\bowtie) \cdot$ A. G. Sitdikov Archeometry Center of Excellence, Kazan Federal University, 18 Kremle vskaya Str., Kazan 420008, Russia

e-mail: eponoma3@uottawa.ca

E. G. Ershova

Department of Biology, Moscow State University, Leninskie Gory 1-12, Moscow 119991, Russia

E. V. Ponomarenko $\cdot$ K. Gajewski

Department of Geography, Environment and Geomatics, University of Ottawa, Ottawa, ON K1N6N5, Canada

M. S. Blinnikov

Geography and Planning Department, School of Public Affairs, St. Cloud State University, St Cloud, MN 56301-4498, USA

(C) The Author(s) 2019

L. E. Yang et al. (eds.), Socio-Environmental Dynamics along the Historical Silk Road, https://doi.org/10.1007/978-3-030-00728-7_19 
Keywords Middle Volga $\cdot$ Archaeology $\cdot$ Population dynamics $\cdot$ Trade routes Land use history $\cdot$ Palynology $\cdot$ Paleoclimatology $\cdot$ Russia $\cdot$ Holocene Little ice age $\cdot$ Medieval warm period $\cdot$ Dark ages cold period Roman warm period

\subsection{Introduction}

In this paper, we provide an overview of the human-environment interactions in the Middle Volga region of Russia during the past 2500 years. Few results of the archaeological research in the region have been published in English, and we therefore present a first summary of the historical and archeological data that have been accumulated over the past century. An important part of this work is a map-based analysis of population dynamics that is linked with a discussion of the trade and landscape development in the region. As the vegetation history and ecosystem dynamics of Middle Volga are poorly understood, we present new paleoecological data obtained from soil profiles and show how these record land use changes over the time period. Finally, we synthesize human and environmental history of the area, and show the potential for future work.

\subsubsection{Study Area}

The Middle Volga (Srednee Povolzhye) is an informal region centered on the middle portion of the Volga River Basin near the confluence of the Volga and Kama rivers (Fig. 19.1). In a narrow sense, it includes four regions of the Russian Federation: Republic of Tatarstan, Penza, Ulyanovsk, and Samara. In some classifications, Mari El Republic, Chuvash Republic, and Saratov Region are also included.

The Middle Volga forms a part of the Middle Russian Province of the East European (Russian) Plain between latitudes of $53^{\circ}$ and $56^{\circ} \mathrm{N}$ and longitudes of $45^{\circ}$ and $52^{\circ}$ E. Elevations range from $150 \mathrm{~m}$ above sea level in the east to $250 \mathrm{~m}$ above sea level west of the Volga River. The Volga River bisects the region flowing mainly from west to east in the northern part and north to south in the southern part, with the city of Kazan located north of the sharp bend. For about $650 \mathrm{~km}$ the Volga River, along with the Kama River in its lower reaches, forms part of the massive Kuybyshev reservoir (built in 1957) with an area of $5900 \mathrm{~km}^{2}$.

The bedrock geology is predominately Paleozoic, Mesozoic and Cenozoic rocks covering the ancient crystalline pre-Cambrian Russian Platform below. Much of the upland area east of the Volga River is underlain by Upper Permian sedimentary rocks, with river valleys and lowlands south of the Kama River underlain by Pliocene rocks. West and south of the Volga River is mostly Jurassic and Cretaceous bedrock.

The most recent, late Valdai glaciation ( $c a .21-18 \mathrm{ka}$; 1000 years before present) did not reach the region, with the main terminal moraines stretching across the Nizhni 
Novgorod and Perm regions far to the west and north. Thus, most of the Quaternary landforms are not glacial, and wind-blown loess deposits are fairly common.

The climate of the region is temperate continental Dfb type (Alisov 1956) with long and cold winters $\left(-14^{\circ} \mathrm{C}\right.$ mean January temperature $)$ and warm summers $\left(19^{\circ} \mathrm{C}\right.$ mean July temperature). The vegetative season lasts between 120 and 150 days. Typical total annual precipitation values are $400 \mathrm{~mm}$ in the south and $600 \mathrm{~mm}$ in the north, more-or-less evenly distributed over the course of the year. Snow cover lasts between 5 and 5.5 months.

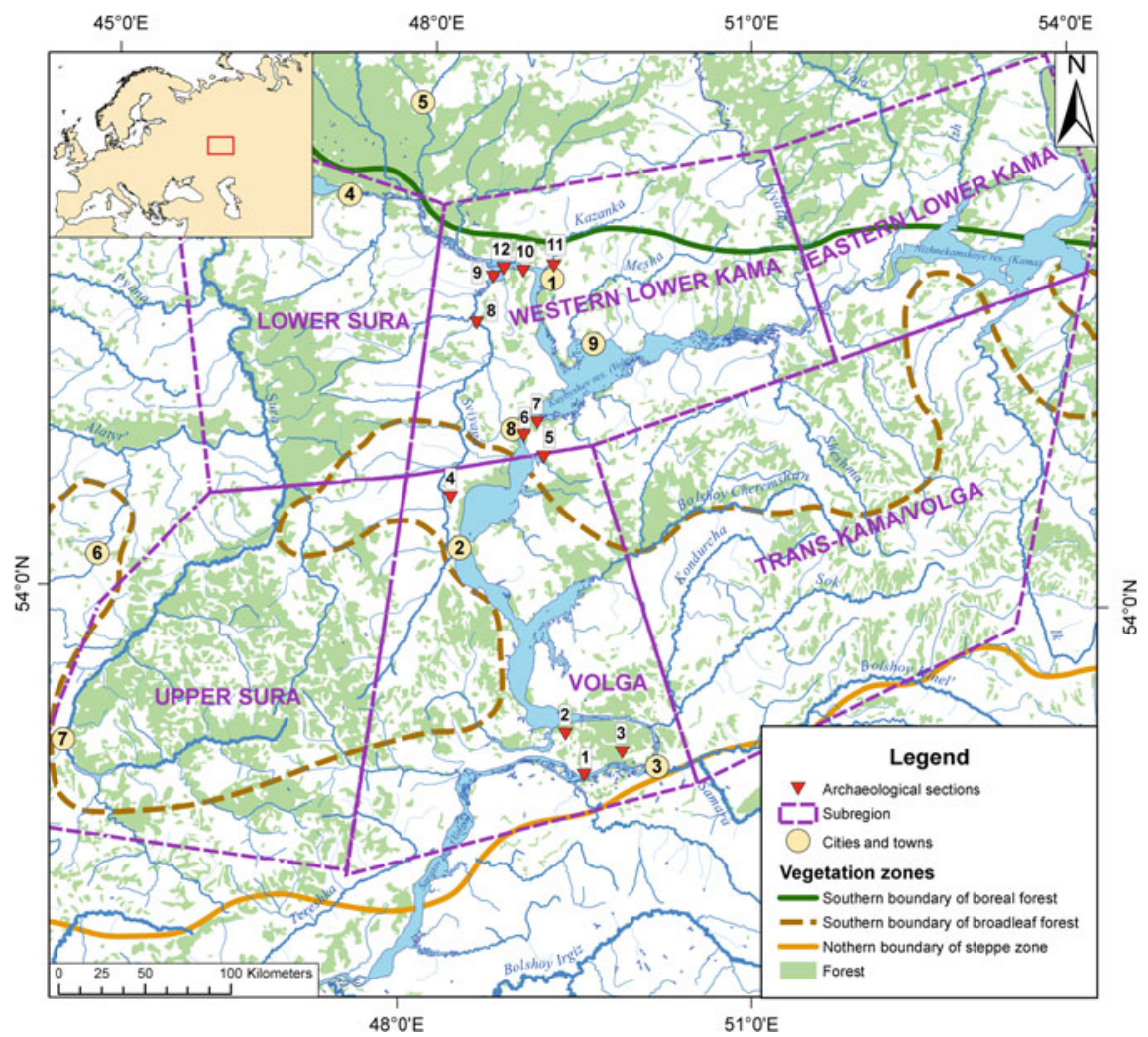

Fig. 19.1 Map of the study area showing the subregions, modern vegetation and major rivers. Sites discussed are noted by numbers, and abbreviations are used in subsequent figures. Red triangles depict study sites/soil sections: 1-Lbische hillfort (Lb); 2-Zhiguliovskiy gully (Zg); 3-Shelekhmet' (Osh-Pando-Ner' 1 and 2 sites) (She); 4-Komarovka ensemble (Ke); 5-Tankeevka fortified settlement (Ta); 6-Urnyak hab. site (Ur); 7-Bolgar (MI-Maly Jerusalimskiy gully, BI-Bolshoy Jerusalimskiy gully, Bo-medieval city of Bolgar, excavation blocks 178, 179, 189, 199); 8-Burunduki hab. site (Bu); 9-Mizinovo hab. site (Ms); 10-Morkvashi site (Mo); 11—Kazanka, smaller hillfort (Ka); 12 -Makar'yeskiy hillfort (MaH). Orange circles depict modern cities and towns: 1-Kazan; 2-Ulyanovsk; 3-Samara; 4-Cheboksary; 5-Yoshkar-Ola; 6-Saransk; 7-Penza; 8-Tetyushi; 9-Laishev 
The Volga-Kama river system is an ancient waterway with deep, well-developed valleys featuring multiple (commonly three to four) terraces of late Pleistocene to mid-Holocene age. The lower terraces are now mainly covered by the reservoir. A thick mantle of alluvial deposits covers the banks, and in the uplands, loess deposits commonly form steep river bluffs along the valley sides.

The region spans the transition from southern taiga to steppe (Fig. 19.1). A continuous forest is present only in the northern part of the study area. In the central and southern part of the region, the forest is preserved only on sandy soils not suitable for modern agriculture and in areas distant from water sources.

North of the Volga River, spruce (Picea abies) is found, while south of the Kama River it occurs only in plantations. The southern limit of its natural distribution today closely tracks the $+20^{\circ} \mathrm{C}$ July isotherm. Pine-dominated forests are widespread and found as far south as southern Tatarstan. They tend to grow on sandy soils and are pyrogenic in origin. Old-growth pine forests, sometimes with a proportion of oak, are found in Ulyanovsk Region on the right bank of the Volga River and north of the Samara Luka region on the left bank. There are also many scattered pine plantations, mostly $<60$ years of age.

Mixed forests with spruce, fir, oak, lime, and elm are found in the extreme north of the area The most common deciduous trees in the primary forests are oak (Quercus robur), small-leaf lime (Tilia cordata), maple (Acer platanoides), ash (Fraxinus) and two species of elm (Ulmus). Scotch pine (Pinus sylvestris), aspen (Populus) and two species of birch (Betula) grow in the secondary forests. Local forest communities occur on the floodplains (willows and alders) and in the steppe ravines (prunes, wild cherry). Oak forests and oak-lime forests are the two most important and presumably ancient forest types in the region. Some oak forests are found on highlands, while others may occur along the rivers on high terraces. Oak is temperature-limited towards the east, where lime replaces it as the dominant broadleaf tree.

The steppe in the region is mainly of the meadow variety with a diverse and common forb community consisting of species from the Rosaceae, Caryophyllaceae, Fabaceae and Asteraceae families and with needlegrass (Stipa spp.) and bunchgrass fescue (Festuca valesiaca, F. pseudovina). Steppes are found locally in small fragments in southernmost Tatarstan and in parts of the Samara and Ulyanovsk regions, although little steppe survives, as much has been transformed into farmlands. While over $50 \%$ of the region is under cultivation today, the remainder is fallow or pastureland $(25 \%)$, forest $(20 \%)$, water and settlements.

In the southern taiga, game is plentiful (brown bear, roe and common deer, moose, wild boar, beaver, capercaillie) and wolf and lynx can still be found. In the steppe, red fox and badger are important, and there are many rodent and shrew species as well. Both the Volga and the Kama river valleys are important migratory corridors for birds. Many of these animals played a major role in the diet of early agriculturalists in the region.

In the past 30 years, much farmland was abandoned and progressively reclaimed by forest. Birch, maple, and elm are the dominant tree species growing on former farmlands and pastures, and pine is a common pioneer species of the previously 
overgrazed slopes. The recolonization by tree and shrub vegetation is especially noticeable in floodplain meadows that were traditionally in high demand for haying.

\subsubsection{Human History of the Area: The Sources of Information}

\subsubsection{Written Sources}

The first written descriptions of Middle Volga landscapes and environment appeared in the 9th to 10th centuries CE. The most important original description of Middle Volga that was written by an eye-witness and survived until our time was "Risala", or "The Journey to the Country of Bulgarians" by Ibn Fadlan, a secretary of the Bagdad Embassy (Journey of Ibn-Fadlan 2016).

\subsubsection{Archaeological Records}

Archaeological research in the Middle Volga region began over 100 years ago. In the initial stage from the end of 19th century to the beginning of 20th century, the most significant archaeological sites of the region were found and the basic typology of archaeological materials was developed. The first maps of archaeological sites were created, and some interesting sites, mainly burials, were excavated. From mid20th century onward, research focused on the development of the chronological and ethnocultural interpretation of findings. Archaeological cultures were determined as complexes of typologically similar sites and artifacts found within a specific area over a certain time period.

A more intensive program of archaeological research between 1950 and $1980 \mathrm{CE}$ produced a large body of data which allowed for the reconstruction of the cultural dynamics in the region. Attempts were made to reconstruct the ethnicity and subsistence of the archaeological cultures. In recent decades, the development of new methods of paleoecological analysis has opened opportunities for the reconstruction of human-environment-subsistence interactions.

\subsubsection{Environmental History of the Area}

Most palynological data for the forest-steppe zone of European Russia have been obtained from bogs and archaeological sites (Serebryannaya 1976; Klimanov and Serebryannaya 1986; Spiridonova 1991), however the age of the layers was either unknown or derived from archaeological seriation. In the entire Middle Volga region, only one systematic palynological study was done in a peat bog, however, it was not radiocarbon dated and was based on small pollen counts (Blagoveshenskaya 2009). Radiocarbon-dated palynological spectra were obtained for peat bogs only in the 
western portion of the forest-steppe zone to the west of the Middle Volga, in the upper Don, Orel, and Kursk regions (Novenko and Olchev 2015; Novenko and Volkova 2015; Novenko et al. 2009, 2011, 2015, 2016). These studies revealed the following environmental phases:

1. 7000-4800 cal year BP: Forest-steppe was the dominant vegetation in the region. The pollen spectra contained 10-55\% arboreal pollen (AP), represented mainly by Pinus with a proportion of Quercus and Tilia. Xerophytic/steppe taxa (e.g., Ephedra) were present. A short-term cooling and increase in moisture were reconstructed for the time period between 6750 and 6500 cal year BP. The first evidence of pastures was found in pollen of Neolithic layers and Bronze Age layers contained evidence for both grazing/pastures and crop production.

2. 4800-1700 cal year BP: Between 4800 and 3700 cal year BP, the forest margin moved southwards, Picea became an ubiquitous component of the pollen spectra and broadleaf taxa increased in abundance. An increase in AP between 3700 and 1700 cal year BP was attributed to climate cooling. Despite this general trend, some sites experienced fire-triggered deforestation during this period.

3. Between 1700 and 1300 cal year BP and from 900 to 700 cal year BP: Firetriggered deforestation was recorded in the area, presumably due to land clearance for agriculture. During the periods between 1300 and 950 and 600-500 cal year $\mathrm{BP}$, elevated AP indicates an increase in forested area.

The area north-west of Samara Luka (Fig. 19.1) was almost entirely forested (pollen was mainly Quercus) in the mid-Holocene, between 6000 and 4500 cal year BP (Blagoveshenskaya 2009). In the early Subboreal, 4500-3200 cal year BP, Betula and Alnus pollen became more abundant, while oak pollen declined. The proportion of arboreal pollen decreased towards the end of the period. The Subatlantic, 2500-700 cal year BP, was marked by an increase in Pinus pollen. This time period was associated with the transition to the Iron Age and spread of agriculturalism in the region. Finally, pollen spectra attributed to the last 2500 years have low proportions of AP, characteristic of the forest-steppe transition zone.

\subsection{Methods}

\subsubsection{Archaeology}

The archaeological data were analyzed at several scales. At the macro-level we analyzed the degree of the development of the territory based on the locations of archaeological sites of Middle Volga published in regional archaeological maps (Archaeological Map of Tatarstan 1981-1990; Burov 1977; History of Samara Volga Region 2000; Archaeological Map of the Chuvash Republic 2013-2015). Sites were ordinated into cultural areas (groups of the archaeological cultures), archaeological cultures and cultural types, and the chronological frame was based on recent publications. In most cases the ages of archaeological sites were determined by relative 
archaeological dating, although some sites were radiocarbon dated. Site topography and location in relation to the distance from water sources was determined. Maps of the distribution of sites for the various time periods were obtained from the database of the Khalikov Institute of Archaeology of the Tatarstan Academy of Sciences (Kazan, Russia) and plotted in ArcGIS. To analyze the degree of development of the territory, the "kernel density" tool in ArcGIS was applied. Subsistence strategies were described according to published data as well as our recent work.

\subsubsection{Paleoclimate Inferences}

Paleoclimate reconstructions of the past 2500 years were obtained from the National Centers for Environmental Information (USA) Paleoclimatology Database (www. ncdc.noaa.gov/paleo). There were no data available from the immediate area, so regional-scale temperature reconstructions of Europe and Asia from the recent PAGES2k global climate synthesis of the past 2000 years were obtained (PAGES2k Consortium 2013). Three longer summer temperature reconstructions based on treerings were available from Europe and Russia (Esper et al. 2012; Büntgen et al. 2016) and also plotted in C2 (Juggins 2007).

\subsubsection{Paleoenvironments}

\subsubsection{Sites}

Our reconstruction of the ecosystem dynamics for the last 2500 years was based on an analysis of 20 sites in the Middle Volga region (Fig. 19.1). Instead of analyzing a continuous chronological sequence of layers in one site, we analyzed synchronous layers from many different sites and then ordinated the results into a chronological sequence. Pollen spectra for each time period were derived from several sites located in different geomorphological positions. We assume that such an approach would reflect both the temporal dynamics of vegetation and spatial variations in the vegetation cover indicative of the local land use structure.

The following deposits were analyzed:

1. Colluvial deposits and immature soils on slopes and in gullies and located in the vicinity of archaeological sites (archaeological ensembles of the Hun, Post-Hun and Khazar periods in Ulyanovsk and Samara Regions).

2. Immature soils and surficial layers of mature soils buried under anthropogenic deposits. Examples are soils buried under earthen fortifications (fortified settlements of the Early Iron Age in the north-western part of Tatarstan) or immature soils that formed on construction debris and buried under the materials that were dug out and redeposited during the next construction stage of the medieval city of Bolgar. 
3. Tree uprooting structures dividing occupational layers of subsequent periods (Hun/post-Hun/Khazar/pre-Mongolian).

In most cases, several layers of different ages were analyzed in each site, varying from two layers in upland sites to 15 in gullies. Occupational layers of habitation sites were generally avoided, as these could be strongly affected by the input of pollen from anthropogenic materials. Layers were synchronized with archaeological cultures based on the presence of diagnostic archaeological artifacts, using radiocarbon dating of charcoal from the layers, or both.

\subsubsection{Soil Pollen Analysis}

Samples were processed by acidification with $10 \% \mathrm{HCl}$, boiling in $10 \% \mathrm{KOH}$, and centrifuging with heavy liquid (sodium polytungstate) (DeVernal et al. 2010). Counting was done on a light microscope with a magnification of 400-1000x, and 250-300 grains were identified per sample. The percentages of pollen taxa were calculated on the basis of total pollen, and the percentage of spores was based on the total number of pollen and spores. A principal components analysis of the more common pollen taxa (mean $>1 \%$ or maximum value $>5 \%$ ) was performed on the correlation matrix to summarize the pollen assemblages.

\subsubsection{Dating of Layers}

The age of selected layers was determined by AMS radiocarbon dating of charcoal. The layers associated with human occupation commonly contain charcoal, moreover, the presence of charcoal is often considered as evidence of human occupation. Archaeological dates were obtained for layers that had a clear cultural affiliation. Not every layer was radiocarbon dated; for some layers in colluvial sequences an approximate age was estimated using the age of a basal layer and calculated accumulation rates. Some undated layers were placed in a chronological order according to their stratigraphic position between radiocarbon-dated layers.

\subsection{Results}

\subsubsection{Outline of the Cultural Dynamics of the Middle Volga Region}

The cultural and economic history of the region can be summarized into eleven periods prior to the modern times (Fig. 19.2). 

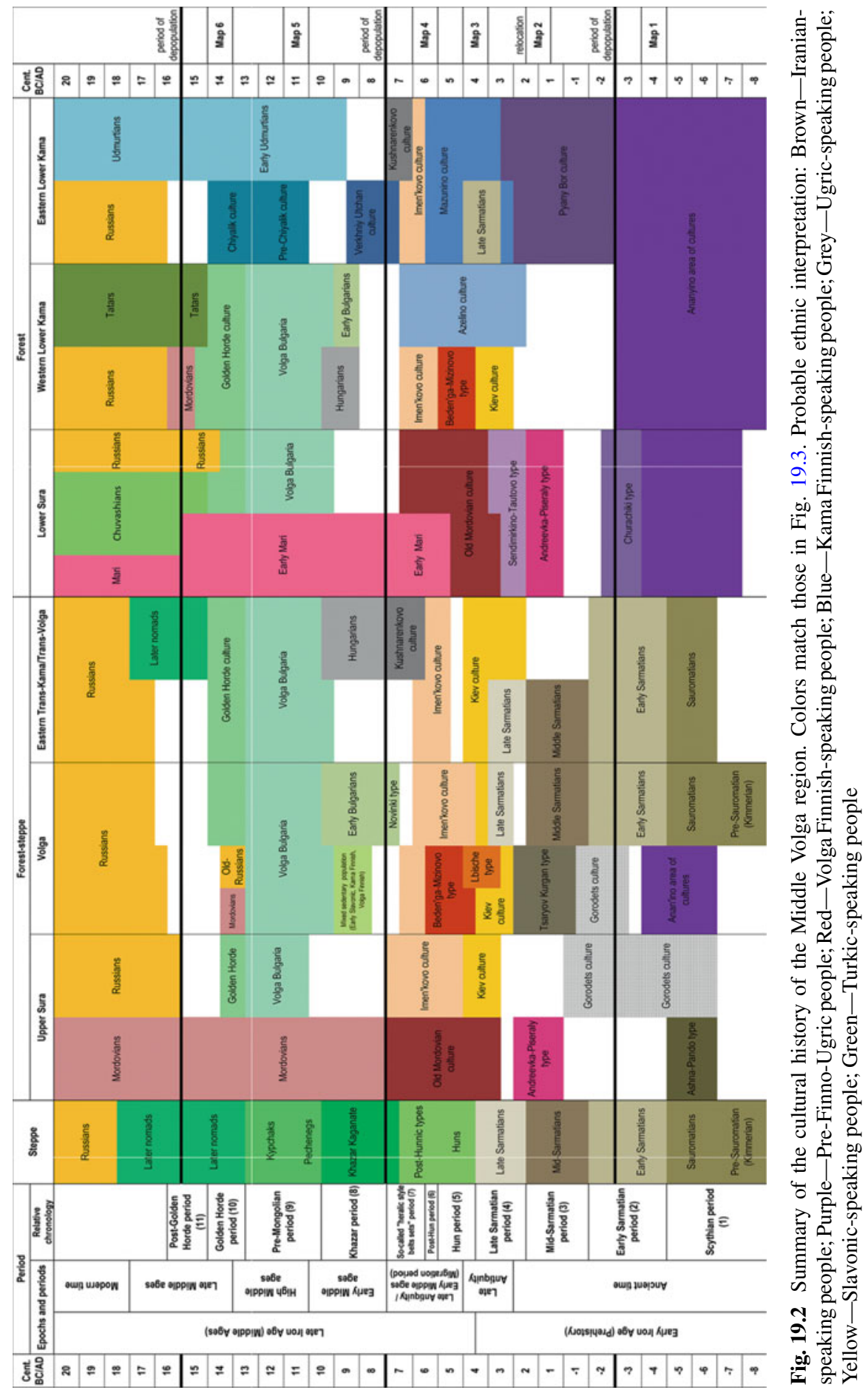


\subsubsection{Scythian Period, 8th-4th Century BCE}

From the 8th to 4th century BCE, the banks of the Volga and Kama rivers were inhabited by several groups of people belonging to the cultures of the Ananyino area (Fig. 19.3, Map 1). There are at least 200 sites of the Ananyino cultures in the region, located within the forested areas. The Ananyino peoples lived in wellprotected bluff forts surrounded by open settlements situated several kilometers apart, on both high and low banks of the largest rivers (Orudzhov 2017). Their subsistence is poorly known but they were undoubtedly pastoralists who used the surrounding forests for hog grazing. There is no clear evidence of agriculturalism (Petrenko 2009; Kuz'minykh and Chizhevsky 2009).

From the 8th to 4th century BCE, the steppes were populated by nomadic Sauromatian people. The northern boundary of the nomadic territories followed a line from Ulyanovsk to the middle reaches of the Bolshoi Cheremshan River and from there to the town of Ufa (Myshkin and Skarbovenko 2000). During the next stage, there was a prolonged depopulation of the Middle Volga region.

\subsubsection{Early-Sarmatian Period, 4th-2nd Century BCE}

The late stage of the cultures of the Ananyino area is dated to the 4th to 2nd century BCE (Chizhevsky 2017), synchronous with the Early Sarmatian culture of the steppe zone of Eastern Europe. At this stage, Ananyino sites were more numerous on the middle Kama River and in the forest-steppe of the Volga region. The disappearance of the cultures of the Ananyino area was followed by a decrease in population and a gradual cultural differentiation of the Middle Volga region. Some groups of people probably lived only at the northern periphery, while the central part was depopulated, except for solitary settlements and hillforts of Gorodets culture in the Volga River valley (Matveeva 2000a).

The Sauromatian culture in Volga-Urals steppe was replaced by the Prokhorovka culture of the 4th-2nd century BCE. The Early Sarmatian culture spread northward of the Kama River (Chizhevsky 2017) through both cultural contacts and also a physical movement of nomadic peoples.

\subsubsection{Mid-Sarmatian Period, 1st Century BCE—2nd Century CE}

Repopulation of the region began in the first centuries CE when two groups of people moved into the broadleaf forest zone (Fig. 19.3, Map 2). In the north-west, sites of Andreevka-Piseraly type appeared (Myasnikov 2013) that played a major role in the formation of Middle Volga Finnish ethnicity, beginning with the OldMordovian culture. Andreevka-Piseraly archaeological sites are distinctive burials of foreign military groups as well as fortified and non-fortified habitation sites. The habitation sites usually have thin occupational layers poor in artifacts, indicating brief occupations. The land-use system and subsistence have not been studied. 


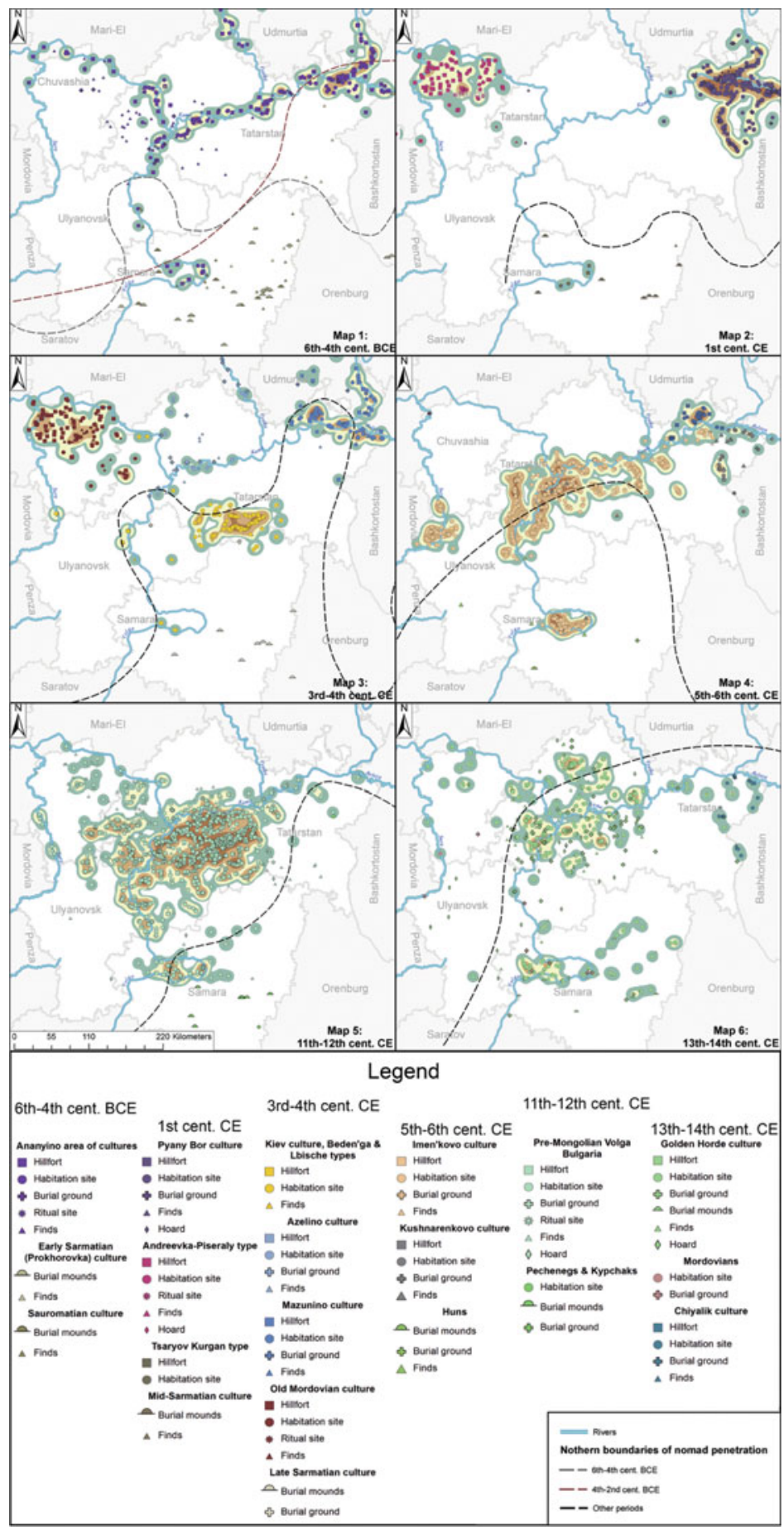

Fig. 19.3 Maps of the distribution of archaeological sites, classified by culture and site type. Colors on the maps match those used in Fig. 19.2 
The Pyany Bor culture expanded into territories north of the Kama and east of the Volga rivers between the 2nd century BCE (shortly before the Mid-Sarmation period) and 2nd century CE (Ageev 1992). Pyany Bor sites were most dense in the lower reaches of Belaya River and adjacent areas of the lower Kama River, where more than 300 habitation and 40 burial sites have been found (Fig. 19.3, Map 2). The subsistence system is interpreted based on site locations. Pyany Bor sites were located on high terraces of rivers with wide floodplains, or occasionally in the floodplains, which may indicate the importance of fishing. Subsistence was presumably based on swidden cultivation and complemented by hunting and pastoralism, focused on horse and cattle livestock (Bugrov et al. 2011).

In the southern and southwestern parts of the region, a few groups of migrants from the southwest (probably from the Don River area), had appeared by this time. The sites of these small sedentary groups, called Tsaryov Kurgan type, are located on high hills in the forest-steppe (Stashenkov 2003; Volkova 2017). Only short-term, solitary archaeological sites have been found, with few artefacts in their occupational layers. Therefore, the Middle Volga region remained largely depopulated until the 3rd century CE. The marginal groups of people inhabiting small areas along rivers had non-specialized multi-faceted subsistence and their impact on the environment at this time period could not have been extensive.

Finally, nomadic groups of the Middle-Sarmatian culture were advancing northwards in the steppes, on the left bank of Volga River, penetrating up to the mouth of the Bolshoy Cheremshan River. Middle-Sarmatian artefacts were also found in several habitation sites in the Samara Luka region (Fig. 19.1) and to the south (Myshkin and Skarbovenko 2000; Matveeva 2003). The movement of nomadic groups into the forest-steppe region was more pronounced in the Early Sarmatian time, from 4th to 2 nd century BCE, as the number of the archaeological sites attributed to nomads of the Middle-Sarmatian time was noticeably smaller (Myshkin and Skarbovenko 2000). It is not yet clear whether the absence of archaeological sites (and population) in the Middle Volga region at the turn of the eras was caused by hostilities among various groups or some other, perhaps environmental factors. However, the depopulation of the area set the stage for intensive exploration of the landscape by newcomers immediately prior to and during the Migration Period.

\subsubsection{Late-Sarmatian Period, Middle of the 2nd to the End of the 4th Century CE}

After a long period of depopulation, a new wave of migration to the Middle Volga region began at the end of 2 nd to the beginning of the 3 rd century $\mathrm{CE}$. Both the local population that lived at the periphery of the region and new migrants from remote areas were part of this process (Fig. 19.3, Map 3). In the Sura River basin, new cultural traditions were developed by descendants of the Andreevka-Piseraly people. They left sites of the Simdimirkino-Tautovo type in the southern part of Chuvashia, and can be considered as the earliest population of the Old-Mordovian culture (Myasnikov 2013). Numerous, but small and poorly fortified hillforts and settlements in the 1st to 2nd quarters of the first millennium CE were located along small streams or ravines 
(Fig. 19.3, Map 2). Tools associated with farming or cattle breeding are unknown, and the economic system is poorly understood.

At the same time, the western part of the Lower Kama region was inhabited by a small but widespread population of the Azelino culture (Gening 1963), who were the descendants of the Pyany Bor cultural tradition (Fig. 19.3, Map 3). The location of the Azelino sites along the large rivers indicates that they migrated from east to west/southwest, eventually crossing the Volga and Kama rivers. Not more than 50 archaeological sites of Azelino Culture are concentrated within the territory of the Volga-Vyatka interfluve. Most are burial grounds; habitation sites have not been sufficiently surveyed (Leschinskaya 2014). Among the findings that characterize the subsistence of the population are many specialized hunting arrowheads, knives for apiculture, skeletons of riding horses (imported from the steppe zone), and skeletons of dogs found in burials. Azelino population subsistence was largely focused on forest resources.

A new group of nomads, termed Late Sarmatians, spread into the steppe zone of Eastern Europe in the 2nd to 4th centuries CE. This population also occupied the left bank of the Volga River; burial grounds were found in the Trans-Volga and Trans-Kama regions (Myshkin and Skarbovenko 2000).

Another population appeared in the forest-steppe zone. One of the groups is the most eastern type of the Kiev culture of the second quarter of the first millennium CE. The oldest sites of this culture appeared in the Trans-Volga area as early as the beginning of the 3rd century CE (Stashenkov 2005). At the same time or slightly later, they also appeared in the valleys of the Sura (Vyazov et al. 2016) and Volga rivers (Vyazov and Semykin 2016). About 140 unfortified sites attributed to this cultural group are located on the low banks and first terraces of small rivers. The settlements were generally several hectares in size, forming long chains of sites spaced 1-2 km apart. Osteological remains indicate that they relied on animal husbandry with a relatively important role of small cattle breeding and with a much smaller proportion of meat provided by hunting (Stashenkov 2005). The role of agriculture has not been sufficiently studied, but they did not have soil tillage implements suitable for ploughing. It is possible that settlements of this population were very short-lived.

A distinct cultural complex of so-called Lbische type appeared in 3rd to 4th century CE in the Samara Luka as a result of migration of sedentary groups from the south and southwest (Stashenkov 2010a). The Lbische people led an isolated life in two large, well-protected hillforts. The absence of wild animal bones in these sites (Petrenko 2011) indicates that they used only domestic cattle as the source of meat. Both the Kiev and Lbische people used small iron sickles that first appeared in the middle Dnieper region among forest-steppe Scythian-influenced cultures and ultimately spread throughout the East-European forest-steppe. The new population of the forest-steppe zone interacted with the Late Sarmatians, whose burials where found in Kiev and Lbische sites (Stashenkov 2005; Matveeva 2000b).

The penetration of the new groups of people into the region did not lead to the disappearance of other cultural traditions. Sites of the Azelino culture became even more numerous and wide-spread, appearing on both banks of the Volga River and in Trans-Kama area (Bugrov 1998). In the eastern part of the lower reaches of the 
Kama, a new culture of Mazunino (Ostanina 1997) developed from the Pyany Bor culture in the 3rd century CE. The subsistence of the Mazunino population followed Pyany Bor traditions of multi-faceted forest utilization with a major role for hunting and gathering. Over 420 Mazunino sites are known and this is a significant increase in comparison to their predecessors. New types of tools, including sickles and narrowblade iron axes, appeared in their tool set. The distribution of sickles may reflect the migrations of Kiev and Lbische people, whereas the appearance of narrow-bladed axes resulted from cultural contacts with the population of the Oka basin. Mazunino sites were commonly hillforts ("palisaded homesteads") of under one hectare in size and located in small river valleys, unlike the Pyany Bor sites associated with wide floodplains (Ostanina 1997). A scattering of pottery shards, common around the hillforts, is usually interpreted as the occupational layers of settlements but can also be associated with agricultural activities. However, evidence for farming is scarce and based on solitary finds of charred cereals. Grinding stones are interpreted as tools for processing crops, which would indicate that the population either produced or traded small amounts of cereals. Osteological remains suggest that hunting played a major role in their subsistence and apiculture knives emphasize the importance of the forests in the economy.

A similar economic system was formed at the opposite edge of the region, in the Sura Basin. Two versions of Old Mordovian culture appeared in the 3rd century CE (Grishakov 2017), located in lower (Myasnikov 2013) and upper reaches of the Sura River (Grishakov 2000). They are considered to be predecessors of the medieval Mordovian population. Therefore, in the 3rd to 4th centuries CE, the landscapes of the Middle Volga region were populated and transformed by groups of migrants from the southwest. The exploration and utilization of the landscape began initially in the forest-steppe, clustered along river valleys. The areas in the vicinity of rivers were dotted by dozens of short-lived settlements located within one to three $\mathrm{km}$ from each other.

\subsubsection{Hunnic Period, from the End of the 4th to the End of the 5th Century CE}

The Hunnic invasion triggered a period of significant cultural transformation. In the late 4th to early 5th centuries CE the entire Eastern European culture was reshaped as cultural relations were destroyed and the vectors of contacts and interactions changed. The Middle Volga region also underwent significant cultural change.

The archaeological remains that are attributed to Huns and related nomads in the steppe zone are solitary burials and findings of (ritual?) bronze cauldrons (Zasetskaya 1994). The northern boundary of their distribution runs along a line from the source of Sura River to the middle reaches of the Bolshoy Cheremshan River and further to the east (Polivanov 1890; Stashenkov 2007; Bogachev 2000). Several groups of well-armed people moved across the Kama River from the southwest (Gening 1976). The changes triggered by the Hun invasion of the steppes occurred also in the foreststeppe zone and in the southern parts of the forest zone, where the Hunnic time was the period of the greatest cultural diversity. 
In addition to the existing Kiev and Lbische population, two more groups of people appeared in the forest-steppe at this time. Short-lived villages and fortified settlements of the Beden'ga-Mizinovo type are found on the west bank of the Volga and in the Sviyaga River valley. The material culture of this type could originate from the Old Mordovian and Kiev culture with some admixture of traits characteristic of Oka Basin Finnish groups. Iron ore mining was an important part of the economy, predominantly surface deposits in the Volga-Sviyaga interfluves (Vyazov and Semykin 2016).

The second and more numerous group of sites are from the early stage of the Imen'kovo culture (Stashenkov 2010b), which appeared along the Volga River and in the middle reaches of the Sura River at the beginning of the Hunnic times (Fig. 19.3, Map 4). The source area for this migration is still unknown (Matveeva 2004). In the early stages, sites of this culture were represented solely by unfortified settlements of one to two hectares confined to the terraces and banks of oxbow lakes (Vyazov 2007). The abundance of fish bones in the sites indicated that fishing was an important part of the Imen'kovo subsistence. Hunting in the forests was apparently as important as raising livestock, as reflected by a high proportion of wild species bones (Petrenko 2011). The large thickness of the occupational layers, which include an abundant and diverse set of household items, and the diversity of archaeological features (e.g., various pits) unequivocally point to the long-term functioning of the Imen'kovo habitation sites. The high density of dwellings suggests large numbers of inhabitants in the settlements. Numerous finds of sickles and dolomitic millstones used for the manual grinding of cereals in the earliest sites of this culture attest to the importance of agriculture (Matveeva 2004). The Imen'kovo people were agriculturalists who developed an economic system more efficient than that of any other cultural groups of Hunnic times in the region.

The Imen'kovo people are believed to be the first truly sedentary inhabitants of the region (Matveeva 2004). The high-efficiency land use system played an important role in the rapid expansion of the Imen'kovo population throughout the Middle Volga in the 5th century, which occurred alongside the disappearance of other cultures or their displacement from the region.

\subsubsection{Post-Hunnic Period, End of the 5th to the Middle of the 6th Century CE}

The boundary between the Hunnnic and post-Hunnic periods in the Middle Volga region is tentative due to the lack of radiocarbon-dated burials and stratified habitation sites. According to our recent radiocarbon datings, it could be set somewhere between the middle of the 5th and the beginning of the 6th centuries CE. The general trends of the regional development that started by the end of the Hunnic time continued during the later period.

By the end of the Hunnic period, the Imen'kovo population was the largest in the region and one of the largest cultural entities of Eastern Europe. By the beginning of the 6th century, the Imen'kovo population occupied the entire forest-steppe zone of the region, while other cultural entities were either forced out of this territory or 
assimilated. The Imen'kovo culture reached its maximum extent in the post-Hunnic times, with over 500 sites, including about 100 hillforts. These are located in the Sura region, in the Sviyaga Valley as well as on the both banks of the Volga and Lower Kama rivers.

During the 5th century, unfortified settlements on the low river terraces ceased to exist and the Imen'kovo population expanded to the high banks of rivers and gullied areas of the upper river terraces. The settlements became spatially structured, with numerous small settlements ("suburbs") clustered around a much larger settlement or a well-protected hillfort (Vyazov 2007) (Fig. 19.3, Map 4).

The change in settlement structure was accompanied by a change in the tool set. The most important example is the appearance of small iron ploughshares, which are more numerous in the sites of Imen'kovo culture than in other cultural formations of Eastern Europe of this time (Vyazov 2008). Larger and more effective sickles and numerous finds of millstones attest to large scale grain production. Finally, narrowbladed axes with socketed heads are frequently found (Vyazov 2012).

The Imen'kovo population caused a significant alteration of the landscapes of the Middle Volga region by the second half of the 5th century. Along with land clearance for habitation sites and agriculture, activities related to mining and processing of iron could have played an important role in changing the landscape.

The agricultural tool set of the Imen'kovo culture is only found in the Middle Volga region, although some components appear in the cultures of the surrounding areas. For example, millstones were found in Mazunino sites, and a short scythe of the late Imen'kovo type was found in one of the late Azelino burials. However, the small number of these findings indicates that the other cultures only borrowed some tools from Imen'kovo, but this was not linked with significant changes in their subsistence.

Nomadic artifacts of post-Hunnic times are limited to areas south and east of the Imen'kovo territory, in Trans-Volga on the border between the forest-steppe and steppe zones. The single burial (Bogachev 2000) and some accidental finds associated with elite groups of nomads were discovered in the Ulyanovsk part of the Middle Volga region, dated either to the first half or mid-6th century CE (Zasetskaya et al. 2007). Apparently, the steppe population of this time was not numerous.

\subsubsection{7 "Heraldic Type Belt Sets" Period, Middle of the 6th to the End of the 7th Century CE}

In the middle of the 6th century, a new migration wave reached the steppe region. It was forced by aggressive Turkic campaigns, which led to the establishment of the Turkic Khaganate. After the Turkic military elite fashion, a new style of belt sets decoration, with belt plates shaped as a heraldic shield, spread over the steppe zone of Eurasia. While the Turkic Khaganate itself did not strongly influence the cultural processes in Eastern Europe, this fashion became popular in the steppe and forest-steppe, from Byzantium to the Altai Mountains, and gave its name to the time 
period. In the Middle Volga region, this period was a time of asynchronous decline of the Imen'kovo culture followed by depopulation of the region.

The reasons behind this process are not fully understood. The latest of the Imen'kovo sites are dated to the first half of the 7th century in most regions east of the Volga. On the right bank of Volga River and on the banks of the Sura River, Imen'kovo sites survived until the middle of the 7th century and perhaps until the beginning of the 8th century (Vyazov et al. 2016). Another very late group of the Imen'kovo population appeared in the eastern part of the Lower Kama region (Gening 1977; Ostanina 2002).

Several groups of newcomers replaced the Imen'kovo population. In the eastern part of Trans-Volga, a new population of the Kushnarenkovo culture (Kazakov 1981), spread in the second half of the 6th century (Fig. 19.3, Map 4). For the first decades, the Kushnarenkovo people lived in contact with the Imen'kovo population from the southern bank of the Kama River to the Samara Luka region, as shown by finds of Kushnarenkovo potsherds in Imen'kovo dwellings. After the collapse of the Imen'kovo culture, the Kushnarenkovo people remained in the Middle Volga region south of the Kama River. The subsistence system of this population is unknown. The presence of very thin occupational layers of the Kushnarenkovo habitation sites is consistent with a relatively mobile, semi-nomadic lifestyle. Descendants of the Kushnarenkovo population are considered to be ancestors of the Hungarians.

To the west of the Kushnarenkovo cultural area, on the left bank of the Volga, several very rich burials of the nomadic aristocracy were found. A set of finds called the "Burakovo hoard" and another discovery in the vicinity of Ulyanovsk (Mukhametshina 1999; Gismatulin 2006) include golden belt attachments dated to the middle of the 7th century CE, probably originating from a destroyed burial. Another group of nomads appeared at the same time or a little later on the right bank of Volga, as indicated by the Shilovka burial mounds (Bagautdinov et al. 1998).

\subsubsection{Khazar Period, from the End of the 7th to the Middle of the 10th Century CE}

The collapse of the Imen'kovo culture was followed by a depopulation of the Middle Volga region in the second half of the 7 th century CE. Occupational sites are recorded only in the periphery of the region. To the west, there was a group of sedentary populations in the Sura River valley, including sites of the Early Mordovian culture and the latest settlements of the Imen'kovo culture. To the east, the Verkhniy Utchan and Kushnarenkovo cultures occupied the eastern part of the Lower Kama region.

By the end of the 7th century, a recolonization of the Middle Volga began. This process continued until at least the second quarter of the 10th century. This period is called the Early Bulgarian time, and corresponds to the Khazar time in the archeology of Eastern Europe. It can be divided into several stages.

The first stage ( 690-750 CE) was initiated by nomads of Turkic (Khazarian and Bulgarian) origin (so called Novinki type): their burial mounds appeared along the Volga, in Samara Luka, and near Ulyanovsk (Matveeva 1998; Bagautdinov et al. 
1998). Small groups of sedentary people, practicing different burial rites and probably of different origin, also appeared in the Volga valley, occupying areas near the nomads as revealed in the Zhiguli archaeological complex in the Samara Luka area (Ponomarenko et al. 2015).

The second stage ( 750-850 CE) was influenced by the defeat of the Khazar Khaganate by Arab forces in 737 CE. In 740-750 CE the area of the Saltov culture became the source of a new wave of migration to the Middle Volga region (Kazakov 1992). The burial grounds of the 8th to 9th centuries were distributed along both banks of the Volga River valley.

At the end of the 8th century, a new group of people appeared in Trans-Volga. Descendants of the Kushnarenkovo culture, recognized as early Hungarians, moved through the Middle Volga along their migration to the Danube (Kazakov 1992). Their largest burial ground, dated from the end of the 8th to the first half of the 9th century, was located far to the north of Samara River.

The number of occupation sites increased and the cultural traits of the sedentary population of the region became more diverse in the 8th century CE. The newcomers moved from the Don basin (Slavonic and Turkic-speaking populations of the Saltov Culture) to west of the Sura river (inhabitated by Mordovians) and Middle Kama region (populated by people of the Nevolino culture). The occupation sites of the first two stages, from the end of the 7th to the middle of the 9th centuries, have comparatively thin occupational layers poor with finds (Stashenkov 2010c), consistent with temporary camps. Most of the occupation sites were situated on high terraces of the Volga and on the banks of second-order ravines, within $10 \mathrm{~km}$ from the river. Many sites were associated with iron ore extraction and iron smelting (Vyazov and Semykin 2016). The newcomers of the Saltov culture were agriculturalists who used ards with iron ploughshares as a plowing tool (Khuzin 2011).

The third stage of migrations to the Middle Volga during the time period from 850 to 910 CE was associated with the decision of the Khazarian rulers to convert to Judaism (Khuzin 2011). As a result, the 9th century was a period of mixing of different cultural groups in the Middle Volga region. The most numerous were migrants with Saltov cultural traditions (mainly of Turkic origins) and Finnish newcomers from the Middle Kama. Archaeological sites include burial grounds and settlements along the Volga and also in the Trans-Volga region, around the future city of Bilyar. Both groups were comparatively numerous, for example, the Tankeevka burial ground contained more than 5000 graves (Khalikova and Kazakov 1977). The territories to the north of Kama remained unpopulated. The total number of sites increased, at least some were used as year-round settlements and some were fortified (Semykin and Matveeva 2010).

The end of the 9th to the beginning of the 10th centuries was the beginning of the Volga Trade Route, connecting the Caspian Sea and Middle East with the Baltic Sea and with the Middle and Upper Kama region, rich with furs. The beginning of the intensive trade is indicated by numerous dirhams and weights found in archaeological sites within the Kama floodplain. Several dirhams from the beginning of the 10th century were also found in the Maly Yerusalimskiy gully site, which is thought to be 
the earliest Bulgarian medieval settlement in the city of Bolgar itself (Khuzin 2011). A Viking presence is also recorded in several sites (Izmaylov 2006).

The peripheral areas remained comparatively poorly populated during the entire Khazarian Period. In the Upper Sura region, only a dozen Early Mordovian sites have been found in a small forested rugged lowland (Belorybkin 2003). The Lower Sura was inhabited by a small group of Early Mari people (Archaeological map of Chuvashia 2013-2015) and the eastern part of the Middle Volga region remained almost totally depopulated except for the Verkniy Utchan group of about 30 sites of the 6th to the 9th centuries (Goldina and Chernykh 2011).

Thus, the repopulation of the region in the 7 th through the 10th centuries advanced from south to north, with areas along the Volga the first to be developed. The locations of the burial grounds and settlements of the 8th through 9th centuries coincide with the route of the Ibn-Fadlan voyage of 920 CE (Journey of Ibn-Fadlan 2016). In the 9th and early 10th centuries, the banks of the Volga were cleared of forest to satisfy the needs of pastures and communication routes. The peripheral areas remained populated during the entire time period, although the marginal groups of peoples did not play a significant role in the process of repopulation.

\subsubsection{Pre-Mongolian Period, Middle of the 10th to the Middle of the 13th Century CE}

No later than the second quarter of the 10th century, the number of habitation sites in the Middle Volga region began to grow explosively, reaching at least several hundred by the beginning of the 11th century (Fakhrutdinov 1975) and exceeding 1500 by the 12 th century. About $15 \%$ of the sites were fortified. Economic development took place on the banks of both the major rivers as well as in the 3rd to 4th order tributaries (Fig. 19.3, Map 5). For the first time, the watershed areas were cleared of forest and used for agriculture. The most populated areas were the valley of the Volga River and the part of Trans-Volga territory south of the Kama River, while Cis-Kama remained poorly developed. A separate group of 30 sites of Pre-Mongolian Volga Bulgarian culture appeared in the southern part of the Upper Sura region, and may be connected with activity on the trade route from Bolgar to Kiev (Belorybkin 2003).

Large fortified towns, including Bilyar, Bolgar, and Suvar, occupied areas up to several hundred hectares and were surrounded by dozens of satellite settlements, typical for medieval urban agglomerations (Khuzin 2006). The economy of PreMongolian Volga Bulgaria was based primarily on crop production using ploughs equipped with wide plowshares and coulters. This highly-efficient type of plough (saban) was capable of cutting and overturning the upper layer of loamy soils. A large number of millstones for hand rotary mills were found in the Volga-Bulgarian sites, indicating high yields and large quantities of cereals. Finds of iron shovel blades point to the development of horticulture and vegetable gardening (Khalikov 2006).

Osteological data from Pre-Mongolian settlements reflect significant changes in the structure of meat consumption, and possibly in the composition of the herds (Petrenko 2006). There was a noticeable increase in the proportion of small cattle, 
implying an increase in the size of open pasture available for goat and sheep grazing. Hunting and especially fishing still played a role in providing the population with protein.

There is extensive data related to the craftsmanship and industries of the Volga Bulgaria economy, which included products made of ferrous and non-ferrous metals, bones, glass, and pottery. The spatial distribution of artifacts reflects the development of highly specialized production of artisan goods in urban centers and its marketing to the countryside. This is evidenced by pottery and blacksmith workshops, craftsman's brands on pottery, and in the high quality of the products. This process certainly had to be accompanied by the development of communication routes and the spread of both local and long-distance trade.

In summary, Pre-Mongolian Volga Bulgaria was a society with a highly developed and multi-faceted economy. The rapid agricultural development of the region, reflected by an explosive increase in the number of settlements, provided the population with food. Towns played an important role in the economy, being centers of craftsmanship and trade. The wide distribution of urban artisan products in the rural areas and the large number of imported products in rural areas are typical for a highly developed territory with extensive communication networks.

\subsubsection{Golden Horde Period, from the Second Half of 13th Century to the $1440 \mathrm{~s}$}

The Mongolian invasion of $1236 \mathrm{CE}$ brought major changes to the cultural and demographic map of the region. Many settlements were demolished, and the majority of large urban settlements never recovered. The catastrophic results of the Mongolian invasion were recorded as fire layers with numerous human remains. The Golden Horde Period in Middle Volga is divided into an the early period (second half of the 13th century to the first half of the 14th century) when they reached the apogee of political and economic power, followed by a period of civil wars and gradual decline from the middle of the 14th century to the 1440s CE.

The Mongolian invasion resulted in the formation of a new political and governmental system in Eastern Europe. The Middle Volga area was a part of the northwestern province of the Mongolian Empire called the Ulus of Jochi. Following the invasion, the majority of the settlements in the forest-steppe and the upper reaches of the Sura simply disappeared (Belorybkin 2003). In Trans-Volga, the number of sites greatly decreased, with sites almost disappearing in the basin of the Bolshoi Cheremshan (Archaeological map of Tatarstan 1990, vol. 6). In Samara Luka, the invasion caused a change in the spatial distribution of settlements (Kochkina 2016) and the arrival of first wave of Mordovian and Russian colonists, probably as a result of the Golden Horde state relocation policy (Stashenkov 2016). The Volga, from Bolgar to the Usa River was desolated (Burov 1977) while the population of the northern part of the former Volga Bulgarian state was less severely affected or else recovered more successfully. Several agglomerations of settlements appeared on the banks of Volga and Kama rivers (Rudenko 2016), the most significant being about 
50 settlements centered on the city of Bolgar, which became the capital of the Ulus of Jochi from the 1240s to1260s (Izmaylov 2009a). The first coins of the Jochides were minted here and its status is attested by the monumental stone architecture of that period (Rudenko 2016). Thus, in 13th through 14th centuries, the areas along the Volga and Kama rivers were densely populated. In the early Golden Horde period the population shifted northwards, exploring the western part of the lower Kama area and including the areas north of the Kama River. The total number of the habitation sites of the Golden Horde period in the region is about 400 (Fakhrutdinov 1975).

The economy of the Golden Horde towns was based on crafts and trades. Although the agriculture of this period has not been extensively studied, an increase in the size of settlements and the adoption of more advanced tillage implements may indicate an increase in productivity (Mardanshina 2008). The local population preferred to get their meat supply buying livestock from steppe nomads rather than breeding them locally (Yavorskaya and Antipina 2016).

The settlements of this period became strongly clustered and agglomerated. During the second half of the 13th to the first half of the 14th centuries, towns and cities flourished along the Volga River valley, from the Caspian Sea to the mouth of the Kama River. The largest cities, such as Kazan, Bolgar, and Muranka site on the Volga River and Juketau on the Kama River were associated with the Volga trade route. The number of urban centers decreased, but their size grew and it is possible that each center marked a separate principality within the Ulus of Jochi. These changes in the spatial structure of settlements could have engendered a large heterogeneity in landscape utilization. The suburbs that provided the citizens with agricultural production were used more intensely than in the Pre-Mongolian period, while the remote areas could have been either under-utilized or abandoned (Fig. 19.3, Map 6).

At the beginning of the second half of the 14th century, the Golden Horde entered a long crisis that ended with the disintegration and collapse of the empire a century later. The crisis could have been caused by ecological, economic or political factors, or perhaps by the Black Death pandemics. The pandemics of 1346 and $1364 \mathrm{CE}$ caused a potentially long-lasting decrease in the urban population. The maximal decrease in a population affected by the plague is reached approximately 140 years after the pandemics (Shamiloglu 2009), so this could account for the depopulation of the region at the end of the 15 th to the beginning of the 16th centuries.

There is indirect evidence for a climatic cause for the destabilization. In the second half of 14th century, winter settlements and burial grounds of nomadic peoples appeared on the southern bank of Kama River. At the same time, nomadic burials appeared in necropolises of sedentary populations, both in cities and villages, as far north as the northern bank of the Kama River (Rudenko 2013). In the second half of the 15th century, artifacts belonging to Nogai nomads appeared in Bilyar (Sitdikov 2016). The northward movement of nomads along with the historical descriptions of droughts (Izmaylov 2009b) attest to climatic changes in the region.

In the 1360s CE, civil war broke in the Ulus of Jochi, providing opportunities for invaders from Russian lands. Evidence of military intrusions includes numerous money hoards, with $70 \%$ of the hoards of the Golden Horde Period in Tatarstan dated 
to the second half of the 14th century (Sitdikov 2016). Some studies documented massacres of the local population (Kochkina 2012).

The late Golden Horde Period was associated with major changes in the spatial distribution and ethnicity of the population of Middle Volga. During the crisis, the population shifted further northward, to the right bank of the Kama River and abandoned the traditional trade centers. Following the depopulation of Trans-Kama and Trans-Volga, the territory north of Kama River became the most densely populated. The centre of economic life shifted from Bolgar to the areas of Kazan and Arsk fortresses that became the heart of the Kazan Khanate.

\subsubsection{Post Golden Horde Period}

The period of the Kazan Khanate from the 1430s to the 1550s is the least-researched period in Middle Volga. Most of the available data, both archaeological and historical, come from the northern part of the region. The most densely populated areas were located north of Volga and Kama and include Cheremis (the medieval name of the Mari people), Chuvash, and Tatars. The southern boundary of their distribution followed the Kama River to its mouth in the west (Sitdikov 2016), with no permanent population south of this line. In Trans-Volga and Trans-Kama, a small sedentary population was concentrated around Bolgar and Bilyar, the largest urban agglomerations now transformed into religious centers. In the 1530s, the Kazan Khans gave the Trans-Volga lands to rulers of Nogai Horde.

The southern part of the region was populated in the late 15th to 16th centuries by nomads of the Nogai Horde. Their summer migration routes covered the entire territory from the Samara River to the Kama River. The Nogai arrived in Middle Volga in the spring, following the left bank of the Volga River. The migration routes of nomads on the right bank of the Volga is unknown, but it is plausible that they used the same routes as the Bulgarians during their migration to Middle Volga. The close proximity of Nogai precluded the development of agriculture in the region and no evidence of permanent settlements of this period has been found, although written sources mention fisheries in Samara Luka starting from the 1520s (Dubman 2012).

In the second half of the 16th century, Kazan was conquered by the army of Muscovy, and the Kazan Khanate became a part of the Muscovy State Territory. The new government begun the construction of forts Svyazhsk (1551), Cheboksary (1555), Laishev (1557), Tetyushi (1578), Samara and Ufa (1586) at major fords of the Kama and Volga Rivers. The forts became the military and administrative centers of the region that protected the newly annexed lands from Nogai, and from the 1570 onwards, from the Cossaks. As a result, a sedentary population gradually established in the territories south of Kama River. 


\subsubsection{Summary}

During the last 2500 years, the development of the Middle Volga region was spatially and chronologically heterogeneous. The first episode of depopulation occurred in the last centuries BCE, and was marked by the disappearance of Ananyino sites in the forest zone and a decrease in the Sarmatian population of the steppe zone. The second depopulation took place in 7th to 8th centuries, following the cessation of Imen'kovo occupation, and the third occurred during the time of the Kazan Khanate.

On the other hand, the subsistence and lifestyle of people living at the periphery of the Middle Volga region, in the forests along Sura River north of Kama River, and especially in the lower reaches of the Belaya River was more conservative, sustainable, and continuous. The anthropogenic transformation of forest landscapes was slower and more gradual than in the forest-steppe zone; large urban agglomerations did not appear until Late-Medieval time, and the population never increased as greatly as in the forest-steppe and steppe zones. It appears that the population utilizing multifaceted forest resources since the Ananyino times was more resilient to various unfavorable circumstances, resulting in a more continuous presence of peoples in the periphery of the region during the times of depopulation and abandonment.

\subsubsection{Trade Networks in the Middle Volga Region}

Trade as an exchange of goods for money or its equivalent appeared in Middle Volga only in the Middle Ages. However, the importance of the earlier, non-monetary forms of exchange of goods and ideas was crucial to the development of local societies. The main vectors of the cultural and trade connections were already defined by the beginning of the 1st millennium CE (Fig. 19.4).

Until the 7th century BCE, most cultural novelties came into the region from the Caucasus and Scythian territories. Later, trade connections shifted eastwards, predominantly to the territories of the nomadic Sauromatian, and later the Sarmatian populations (Kuz'minykh and Chizhevsky 2009). In the 5th to the 3rd centuries BCE, trade goods were imported to Middle Volga from the east. The source areas of the long-distance trade in the time of the Ananyino group of cultures were the regions of the Achaemenids Empire: the Eastern Mediterranean, Egypt, Iranian Plateau, and countries of the Persian Gulf (Ivanov 1997).

With the formation of the northern branch of the Great Silk Route (GSR) in the 1st century CE, the territories of Middle Volga and Cis-Kama functioned as one of the corridors that connected North-Eastern Europe and the countries participating in transcontinental trade along the GSR. From this time onwards, imports into the forest zone of Eastern Europe through nomadic intermediaries noticeably increased. The sources of imports changed as well; among the trade goods were artifacts from the Far East as well as Roman artifacts and coins. Imported goods circulated in the north-western and north-eastern periphery of the region among the peoples of the Pyany Bor culture and in contemporaneous sites of Andreevka-Pyseraly type. The 


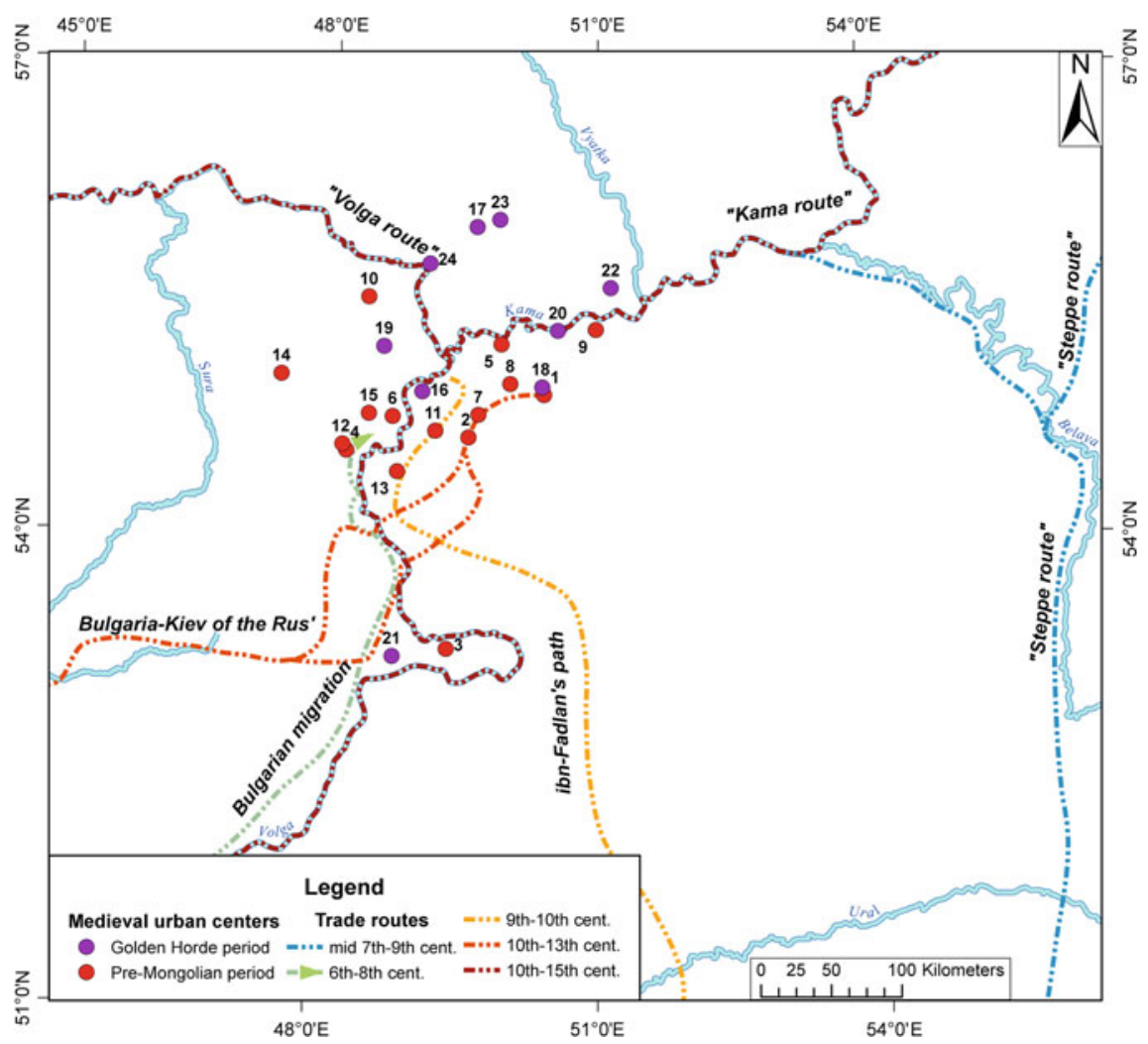

Fig. 19.4 Map showing major trading routes on Middle Volga. Urban centers (italicized are names of archaeological sites): 1-Bilyar; 2-Suvar; 3-Muromskiy Gorodok site; 4-Staroye Aleykino site; 5-Gorodok site; 6-Bogdashkino site; 7-Krasnyj Kluch site; 8-Romodan site; 9-Malaya Polyanka site; 10—Gorodische site; 11-Kokryat' site; 12-Krasnoye Syundyukovo site; 13-Yurmanki site; 14-Tigashevo site; 15-Khulash; 16-Bolgar; 17-Iske-Kazan site; 18-Balynguz site; 19—Shongut; 20—Juketau; 21—Muranka site; 22—Kirmen; 23-Arsk; 24-Kazan

two groups interacted, as indicated by the finds of Pyany Bor artifacts in AndreevkaPyseraly sites and vice versa. The imported goods were largely related to clothing, suggesting that they resulted from migration processes rather than the trade itself.

Based on the distribution of the imported artifacts in sites of the 1st to 2nd centuries $\mathrm{CE}$, the interaction between populations of the steppe and forest zones was most active outside of the Middle Volga region, in the interfluves of the Oka and Sura rivers in the west and along Belaya River in the east. The Sarmatians retained their role of the main mediator between the forest and steppe populations during the second quarter of the 1st millennium CE, and Late Sarmatian artifacts were widely used by the populations of Azelino and Mazunino cultures. 
The appearance of peoples of the Kiev culture in the Middle Volga in the 3rd to 4th centuries CE marks the formation of a new intercultural communication that connected Middle Volga with the Don region, the left bank of Dnieper River, and possibly even with regions further west. This route approximately follows the modern southern boundary of the forest-steppe zone. Important agricultural innovations, coins from the Bosporus and Rome, and metal ingots used by local people for jewelry making were transported to Middle Volga along this route.

The trade networks underwent major changes in Hunnic times, when the amount of imports greatly decreased. The decrease in southern imports was possibly caused by a decline in the steppe population of the Volga-Ural region due to their involvement in the Hunnic military efforts. At that time, the forest-steppe route that connected Middle Volga region with the Don and Dnieper basins disappeared.

In the 6th century CE, the population of Imen'kovo established some connections with the Cis-Caucasus and Northern Caucasus regions. Sassanid drachmas are found in three sites, one in Samara Luka and two on the northern bank of Kama River. The context indicates that they were used as raw material for metal working. It is unclear whether the coins were transported along terrestrial or water routes, but the routes were definitely tied to the Volga River, as indicated by other finds of Byzantine and Sassanid coins of the 6th century CE. The erection of fortresses of Imen'kovo culture occurred within the narrow time period from the end of the 5th to the 6th century CE. Their location on high banks of large rivers and the form of their structures suggest that their main function was protection from riverside. The finds of camel bones in several Imen'kovo fortresses are suggested to be consistent with terrestrial trade routes.

In the middle of the 7 th century $\mathrm{CE}$, the Belaya River valley became the main trade route connecting the steppes with the densely populated areas along the Kama. Sassanid and Byzantine coins and toreutic objects accumulated in Khwarezm, Central Asia, after Arabian conquests were distributed in large numbers along this route. Historical descriptions indicate another route along the western bank of the Volga River that was used for movement by various groups of peoples.

Not later than by 9th century, a caravan trade route from Khwarezm to the Middle Volga was established. This route connected the Ustyurt Plateau with the left bank of the Volga River near present-day Samara, and continued north along the left bank of the Volga and up its interfluves with the Kama River, forming a large loop to the west. The distribution of archaeological sites of this time is associated with this route, and most places where the route crossed Volga tributaries contain Early Bulgarian burial grounds. In the early 10th century, Samanid dirhams were brought from Middle Volga to Northern Europe by this route. The establishment of the trade route that connected Middle Volga with Khwarezm, bypassing the Lower Volga region and the Khazarian Khanate, provided the Bulgarian rulers with independence from the Khazarian Khanate. The formation of a new political union in Middle Volga shifted Volga-Kaspian trade routes. Prior to the 10th century CE, most goods travelled from the Upper Volga to the Oka, then to the Don, and finally to the Lower Volga rivers. In the 10th century, the main trade route shifted to the Middle Volga region, as reflected 
in the finds of Scandinavian objects in archaeological sites of the end of 9th through the 10th centuries on the Middle Volga (Valeev 2010).

The development of towns and urban craftsmanship in the Middle Volga led to the export of artisan objects from Volga Bulgaria to the Russian Principalities (Rus') along the Volga waterway. The growing trade resulted in the establishment of a new terrestrial trade route that connected the towns of Volga Bulgaria with Rus'. The trade networks established in the 10th through 11th centuries continued until the Mongolian invasion of the 13th century, with the most extensive trade activity along the Volga route between the 10th century and the first half of the 12th century (Motsya and Khalikov 1997). Most Western and Northern European imports reached the territory of Volga Bulgaria during this period while considerable quantitates of Bulgarian goods were also transported north along Volga River (Valeev 2010).

Beginning in the second half of the 11th century, a series of military conflicts occurred between Russian and Bulgarian dukes (in 1088, 1107 and 1120 CE), marking the increasing Russian influence in the north-western periphery of Bulgarian lands. After $1160 \mathrm{CE}$, the growing power of the Vladimir-Suzdal' principality led to a new series of conflicts between 1164 and 1220 CE (Izmaylov 2006). The Rus'Bulgarian confrontation coincided with the decline of the Volga trade transit as Bulgarian imports could not pass the borders of the Vladimir-Suzdal' principality (Poluboyarinova 2006).

These conflicts were probably one of the factors that led to the development of a new terrestrial trade route that connected Volga Bulgaria with the southern part of Rus' in the 12th to the 13th centuries. The historical descriptions of this Middle Volga route are supported by archaeological finds of Old-Russian artifacts along the route (Motsya and Khalikov 1997), although the exact location of this route is disputed (Belorybkin 2003; Viskalin 1992; Gismatulin 2014). It is possible that several parallel routes were in operation at the same time. A new group of archaeological sites with a material culture closely resembling that of Pre-Mongolian Volga-Bulgaria first appeared in the upper reaches of the Sura River in the 10th century, and flourished in the 12 th to 13 th century, probably in association with this new trade route (Belorybkin 2003).

Despite the decreasing trade with Northern and Western Europe, the Volga route retained its importance as the major transit of furs to the Islamic countries. The source areas of fur were lands along mid- to upper reaches of the Kama River (Belavin 200). The main trading partner of Volga Bulgaria on the Lower Volga was the city of Suksin, which acted as mediator in the trade between the Middle Volga population, Iran and the Trans-Caucasus (Vasil'yev 2015). Trade activities along the Kama were accompanied by expansion of Volga Bulgaria (Belavin 2000).

The Mongolian conquest radically changed the system of East-European trade communications, due to the disappearance of major trade centers and the desolation of entire regions. However, during the reign of the Golden Horde the vast area of the empire was governed by strong leaders who maintained routes in strict order and considered trade as the basis of state wealth. Importantly, the Middle Volga region was chosen as the centre of the Ulus of Jochi, with the first capital of the Golden Horde khans in Bolgar. 
Golden Horde trade peaked in the second half of the 13th to the first half of the 14th centuries. The largest cities, craft centers and urban agglomerations were located along the Volga River, which was the main trade route, and by the 13th century, Bolgar had become the main transit city on the route (Yemanov 1995). Archaeological evidence of intensive trade includes numerous finds of imported goods and coins. The beginning of 14th century is marked by the growth of cities along the lower reaches of Volga River, reflecting a shift of the trade centers to this region (Nedashkovsky 2009). Trade declined following the crises, pandemics, and civil war that began in the 1360s. Numerous coin hoards were buried during these times of change.

The attempts of the Tokhtamysh government to stabilize the situation in the 1380s CE were unsuccessful, and the invasion by Tamerlan in 1395-1396 CE further deepened the economic crisis. After a series of military conflicts with the dukes of Muskovy in the second quarter of 15 th century, the role of the regional trade center was relegated to Kazan. From this time on, the economy of the region was gradually incorporated into the sphere of the strengthening Muscovy State that became the major trade partner of Kazan.

In summary, the dynamics of trade networks on the Middle Volga depended on political influences, the density of population, and degree of territorial development along the trade routes.

\subsubsection{Climate History of the Past Two Millennia}

Over the past few thousand years, there has been a long-term cooling in northern hemisphere continental regions, later interrupted by the recent warming, which goes by the general term "neoglaciation". This cooling is seen in the majority of paleoclimate records (PAGES2k Consortium 2013), although it tends to be underestimated if only tree-ring records are included (Esper et al. 2012). Superimposed on this neoglacial cooling are shorter-term variations in temperature that can last several hundred years, with transitions of up to several hundred years between them. Because these periods are superimposed on the long-term cooling trend, the variability tends to increase over time (Gajewski 1987; Viau et al. 2006).

Shorter-term variations seem to be frequently forced by volcanic activity (Büntgen et al. 2016; Sigl et al. 2015; Stoffel et al. 2015) or solar variability, but overall, the causes are not entirely understood. Several studies note that intense volcanic eruptions can cause reduced temperatures globally that last for a few years (Büntgen et al. 2016; Sigl et al. 2015; Stoffel et al. 2015). Determining the impacts of these on human activities is dependent on a very precise chronology.

The climate of the past two millennia can be divided into five general periods of alternating cool and warm climates (e.g., PAGES2k Consortium 2013; Büntgen et al. 2016; Helama et al. 2017b). These were not uniformly cold or warm and furthermore temperature is only one component of the climate. However, long-term changes in temperature are associated with changes in the atmospheric general circulation, so a protracted period of warm or cool temperatures would be associated with changes in 


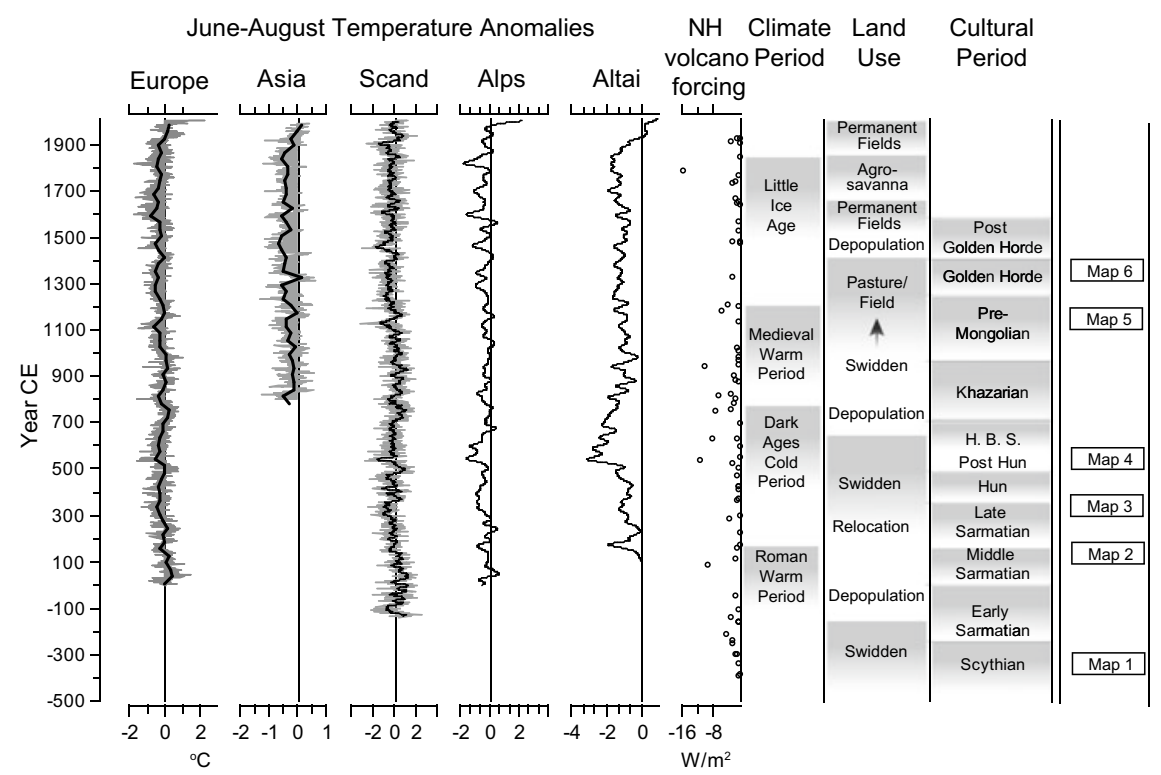

Fig. 19.5 Several paleoclimate reconstructions relevant to the Middle Volga region. Sources for the series are: (a) Europe and (b) Asia standardized June-July-August temperatures from PAGES2k Consortium (2013). Grey is annual values and black lines are 30-year means. (c) JJA temperatures anomalies (with respect to AD 1951-1980) from tree ring densities from Scandinavia (Esper et al. 2012). Grey line indicates annual values and black line is an 11-year running mean. JJA temperature anomalies based on normalized tree-ring width series from (d) Alps and (e) Altai mountains (Büntgen et al. 2016); shown are the 40-year spline fits to the data. (f) Northern Hemisphere volcanic eruptions (Sigl et al. 2015); units are estimated forcing in $\mathrm{Wm}^{-2}$. Summary of the (g) climate, (h) land use and (i) cultural periods as discussed in the text. H.B.S is Heraldic Belt Set. The time of the maps in Fig. 19.3 is shown in (j)

pressure patterns, thereby affecting precipitation and other climate variables as well. The periods are not distinct and the transition between these periods can be of short or long duration (Fig. 19.5).

1. Roman Warm Period (1-300 CE) (Ljungqvist 2010; Esper et al. 2012; McCormick et al. 2012). Esper et al. (2012) consider this period to be warmer than present in Scandinavia, as it was superimposed on a long-term cooling. The extent and intensity of this period are not as well-known as subsequent periods.

2. Dark Ages Cold Period (410-775 CE) (Helama et al. 2017b). The Dark Ages Cold Period was associated with the migration period by Helama et al. (2017b). It was generally cool and frequently relatively wet. The typical span of this period in various records is 370 years, with coldest temperatures around $625 \mathrm{CE}$. Büntgen et al. (2016) consider the period between 536-660 CE as an extensive, volcanically-caused cold period, although Helama et al. (2017a) question its extent. Many studies have shown societal impacts of the climate at this time (Büntgen et al. 2016). 
3. Medieval Warm Period (850-1200 CE) (PAGES2k Consortium 2013). This period is generally considered warm, although with considerable variability, especially between regions. As with the subsequent Little Ice Age, peak periods of warm or cool temperatures tend to vary spatially.

4. Little Ice Age (1450-1850 CE) (PAGES2k Consortium 2013) This is probably the best defined and consistently-seen climate episode. There are several times of more-or-less cool conditions, for example, the 1600s-1850 CE are general cold.

5. Modern Period (1850 CE -present). The modern period is characterized by the human-caused global warming.

\subsubsection{Land Use and Vegetation History of the Region}

\subsubsection{Pollen Record}

The vegetation dynamics in the region during the last 2500 years can be divided into two major periods: a predominantly forested landscape prior to 12 th century $\mathrm{CE}$ and a mosaic of open habitats and patches of forests, composed mainly of early successional and light-demanding taxa (pine and birch) from 12th century CE onwards (Fig. 19.5). The boundary between the two lies at the end of the Pre-Mongolian Period. Although the proportion of taxa associated with open habitats increased during the Medieval Warm Period, the threshold change occurred ca 200 years later (Fig. 19.6). Major transitions in the vegetation cover coincided with changes in both the population density and settlements pattern, allowing for an assumption that these changes were correlated. Therefore, more subtle changes of the pollen spectra within each of the two time periods can be interpreted as result of changes in the land-use structure.

\subsubsection{Principal Component Analysis}

A principal components analysis of the pollen data summarizes the pollen assemblages and permits the division of the data into zones (Fig. 19.7). The pollen taxa form four distinct groups of variables with highly correlated groups of taxa that can be interpreted as associations caused by different land use types. Types 1 and 4 are well-defined, while differences between the types 2 and 3 are less distinct, consistent with the interconnectedness of these land-use types.

- Type 1 (swidden) includes tree pollen such as Betula, Tilia, and shrubs such as Alnus and Corylus. These taxa were more abundant in older sections. Although Pinus, a species commonly associated with fires is absent, the presence of shrubs and Onagraceae pollen (Chamerion, fireweed) indicates the presence of fires during this time, associated with swidden agriculture. This combination is consistent with the managed burning of the forest in the form of slash-and-burn cultivation.

- Type 2 (pasture) includes non-arboreal pollen (NAP) of meadow taxa indicative of pastures and abandoned farmlands, such as Poaceae, Brassicaceae, and Asteraceae. These spectra become more abundant in the recent past and indicate the presence of pastures. 


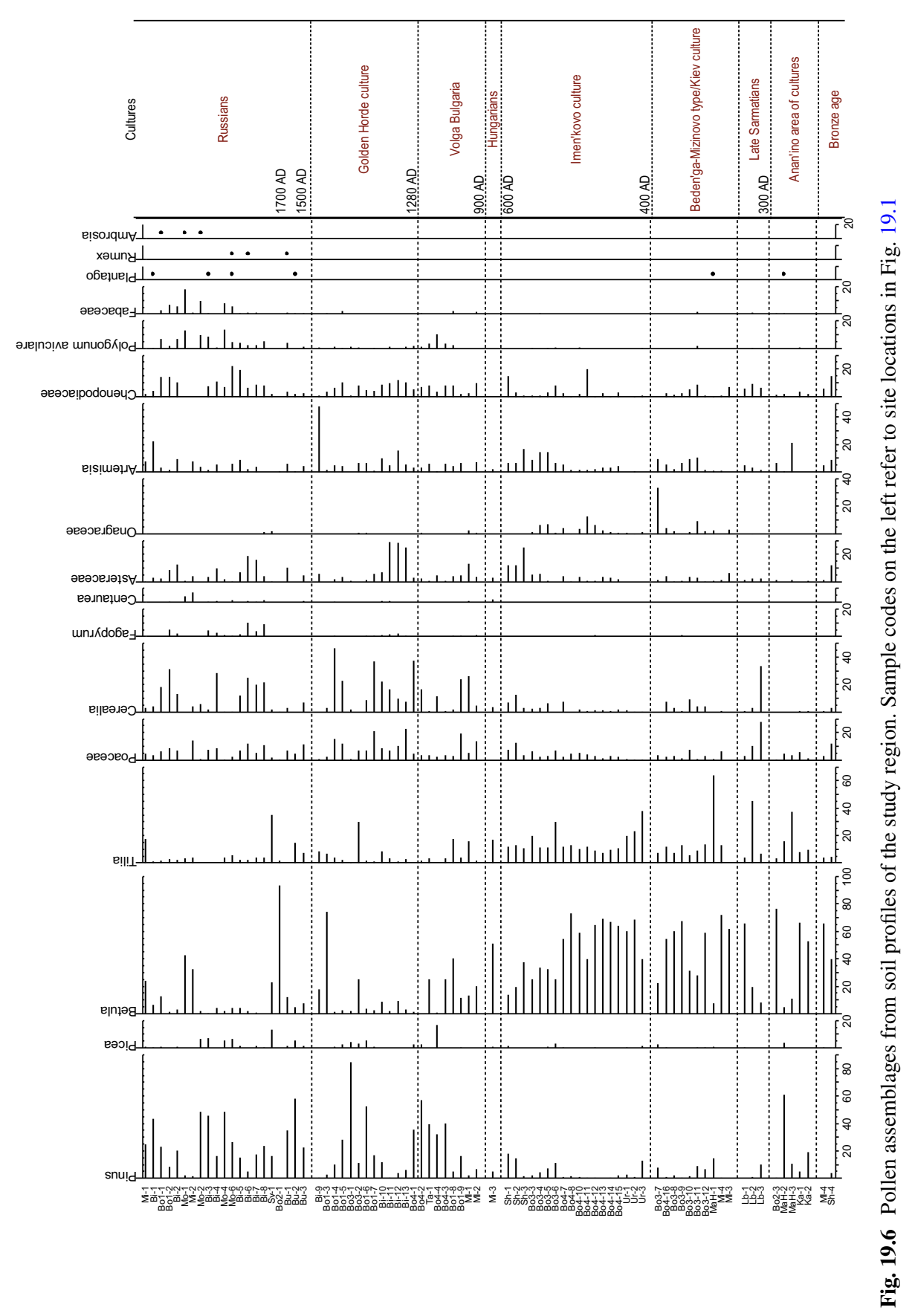



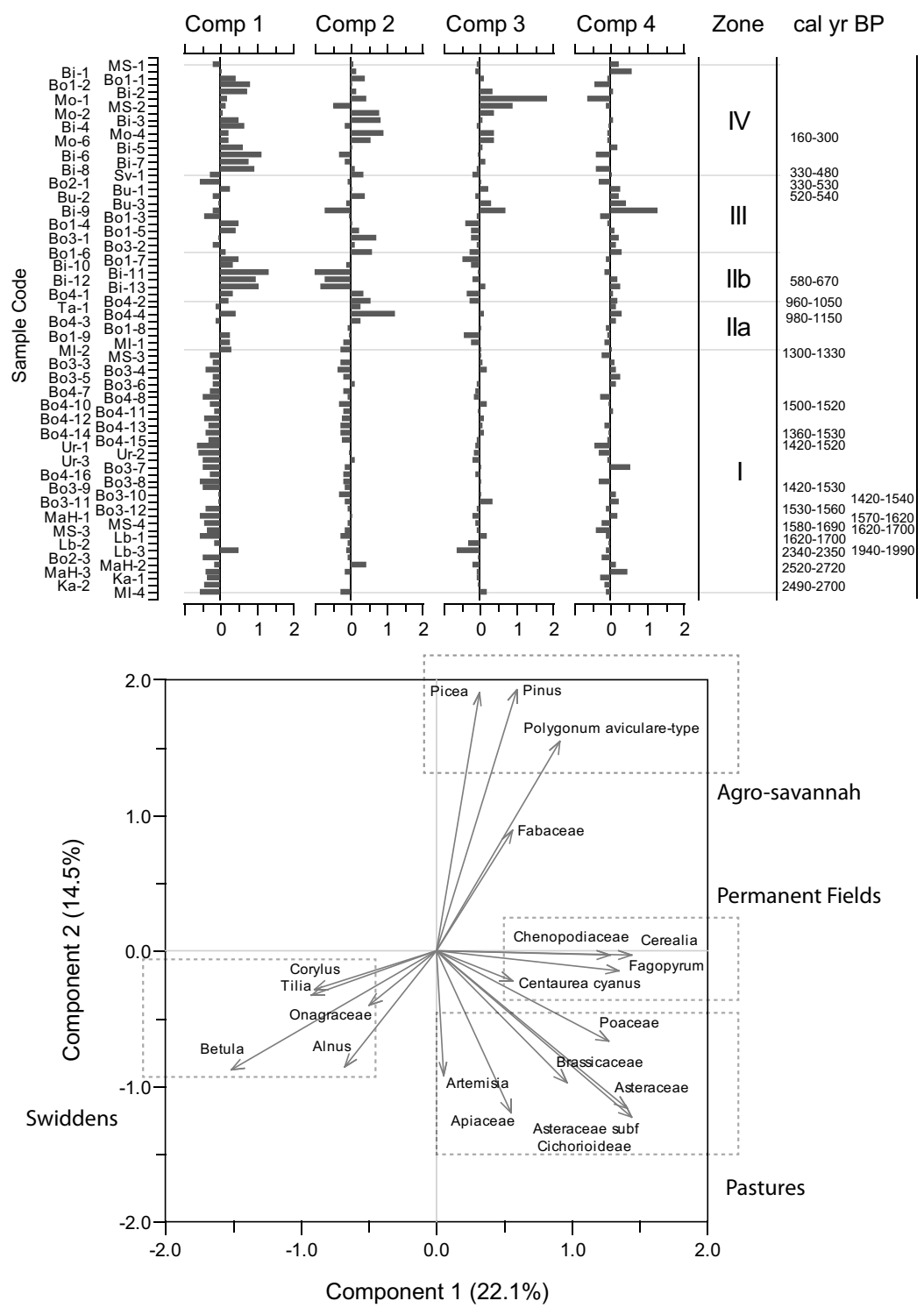

Fig. 19.7 Principal components analysis of the pollen data in Fig. 19.6. Zones are based on major transitions in the component scores. The first component explains $22.1 \%$ of the variance, the second $14.5 \%$, the third $10.2 \%$ and the fourth $7.9 \%$. Correlated groups of taxa and their interpretation (see text) are indicated by dotted rectangles

- Type 3 (permanent fields) includes cultivars and their weeds, some of which can grow in both functioning and abandoned farmlands. Pollen includes Cerealia and Fagopyrum (taxa characteristic of permanent fields), and Chenopodiaceae (weeds). 
These were important in the recent past and also during the time of zone IIb (Fig. 19.7).

- Type 4 (agro-savannah) includes taxa associated with soil compaction and roads (Polygonum aviuculare) as well as coniferous trees (Picea and Pinus) along with Fabaceae. This group is highly loaded on the second component, and is most abundant in the more recent assemblages. The dominance of coniferous taxa is typical of landscapes with extensive herbivory, such as the long-term utilization of forest pastures and selective extraction of deciduous trees for firewood. Arboreal pollen (AP) was dominated by the pollen of pine that could, however, be transported from hundreds of kilometers away. The open landscape with patches of grazed/selectively logged forest was similar to type 3, but presumably had a greater proportion of forested patches.

Apparently, the combination of taxa does not mean that these plants grew in the same habitats, it reflects their co-existence in the landscape. For example, road networks (Polygonum aviculare), pastures/meadows (Fabaceae), and secondary coniferous forests (Pinus, Picea) appear simultaneously and their appearance is not independent (they are correlated).

\subsection{Discussion}

The development of the landscapes of the central part of the Middle Volga region in the last 2500 years was a discontinuous process of the explosive growth of population and land utilization alternating with stages of depopulation and desolation. Periods of depopulation or major changes in settlement locations seem to occur at similar times as climate changes (Fig. 19.5). Some cultures were associated with distinct climatic episodes, such as association of the Dark Ages Cold Period with the Hun, Post Hun, Heraldic, and Khazarian times, and the Medieval Warm Period with the time of Volga Bulgaria.

Depopulations of the area were associated with the transitions between cultures and also with transitions between the climate regimes. However, this does not explain the complexity of interactions between the peoples and the environment. The subsistence and land use strategies changed through time, and the landscape changed accordingly. The settlements and land use were concentrated along rivers until 10th century and from this time onward, watersheds were included in the pattern of agricultural utilization.

The land use signatures are reflected in palynological spectra as specific combinations of plant taxa associated with the times of occupation by the population of certain archaeological cultures (Fig. 19.7). The boundaries between palynological zones generally coincide with the chronological boundaries between archaeological cultures (Fig. 19.5). The major archaeological time periods have distinct palynological signatures, suggesting that changes in land use can be associated with the various cultures. Moreover, major changes in vegetation occurred rapidly, within one to three 
centuries, so it may be possible to use the forest cover composition as a chronological tool in archaeological studies. Furthermore, not only combinations of taxa, but also some indicator taxa have a clear chronological affiliation. For example, Onagraceae pollen are prominent only between 1700 and 1300 cal year BP (Beden'ga-Mizinovo type and Imen'kovo culture) and Picea pollen appeared in the pollen spectra at levels exceeding $1 \%$ only towards the end of the Pre-Mongolian time, in the 1200s. Fagopyrum is predominantly associated with the most recent 500-year period.

Swidden pollen spectra are associated with the occupation of the area by the people of the Beden'ga-Mizinovo type, the Imen'kovo culture and by the early Bulgarians. Episodes of land clearance using swidden techniques apparently also occurred in the beginning of the Russian colonization. A combination of taxa similar to the swidden group was recorded for the Ananyino occupations, but Onagraceae and Cerealia (marker components of slash-and-burn cultivation) were absent; more sites need to be analyzed for definitive conclusions.

During the Pre-Mongolian Period, the combinations of pollen taxa/land use types changed from swidden to pasture and further to agro-savannah in less than 300 years. Swidden techniques were applied to clear the forested landscape in the beginning of colonization and, shortly thereafter, permanent fields and pastures were established on the cleared lands.

Pasture land use was prominent during the Golden Horde time, 580-670 cal year $\mathrm{BP}$, alternating with fields and farmlands. During the pasture phase, the diversity of the local vegetation cover was maximal, with the percentage of arboreal pollen fluctuating from near-zero to almost $100 \%$ at various times and locations.

Agro-savannah is associated with the period of the Russian colonization. However, fields, pastures, farmland and agro-savannah pollen spectra alternated during the last 500 years, reflecting changes in the intensity of the anthropogenic impact. The percentage of arboreal pollen indicating forest cover was higher in the beginning of the Russian colonization, in the 1500s to the 1700s, and in the recent decades following the collapse of the Soviet Union and communal farming. Several peaks of birch pollen within the last 500 years marked the short-term abandonment of agricultural lands during times of social instabilities.

The formation of the anthropogenic landscape occurred in the Pre-Mongolian Volga Bulgaria time, during the 11th through the mid-13th centuries. The beginning of this period coincided with the Medieval Warm Period that perhaps facilitated the process of deforestation in the region. At this time, an agricultural landscape of a nearly modern appearance was shaped, with stable/well-defined boundaries between fields and forests, permanent fields, and road networks.

Acknowledgements Ayrat Sitdikov is supported by a grant of the Russian Foundation for Basic Research, project 17-46-160812 "Natural and anthropogenic landscapes of Trans-Kama region in Middle Ages". K. Gajewski is supported by a Discovery Grant from the Natural Sciences and Engineering Research Council of Canada. 


\section{References}

\section{In English/French}

Büntgen, U., Myglan, V., Ljungqvist, F., et al. (2016). Cooling and societal change during the late antique little ice age from 536 to around 660 AD. Nature Geoscience, 9, 231-236. https://doi. org/10.1038/ngeo2652.

Chizhevsky, A. A. (2017). Monuments of the late Ananyino cultural and historical region (Pamyatniki pozdnego perioda Ananinskoy kulturno-istoricheskoy oblasti // Arkheologiya Evraziyskikh stepey. N 4). Archaeology of the Eurasian Steppes, 4, 196-256.

De Vernal, A., Henry, M., \& Bilodeau, G. (2010). Micropaleontological preparation techniques and analyses. Les Cahiers du GEOTOP 3. http://www.geotop.ca/.

Esper, J., Frank, D., Timonen, M., et al. (2012). Orbital forcing of tree-ring data. Nature Climate Change, 2, 862-866. https://doi.org/10.1038/nclimate1589.

Gajewski, K. (1987). Climatic impacts on the vegetation of eastern North America for the past 2000 years. Vegetatio, 68, 179-190.

Helama, S., Jones, P., \& Briffa, K. (2017a). Limited late antique cooling. Nature Geoscience, 10, 242-243. https://doi.org/10.1038/ngeo2926.

Helama, S., Jones, P., \& Briffa, K. (2017b). Dark ages cold period: A literature review and directions for future research. Holocene, 27, 1600-1606.

Juggins, S. (2007). C2. Software for ecological and palaeoecological data analysis and visualization. Version 1.5. http://www.staff.ncl.ac.uk/stephen.juggins. Last accessed 13 Feb 2018.

Khalikova, E. A., \& Kazakov, E. P. (1977). Le cimetiere de Tankeevka. Les anciens Hongrois et les ethnies voisines a l'Est. Studia Archaeologica, 6, 7-221.

Kochkina, A. F. (2012). Malaya Ryazan' 2 settlement is a Russian village on the Samara Luka. In: Middle Volga region in the context of the Russian medieval history. Conference proceedings on the crossroads of cultures (from the end of the 13th cent to the 16th cent). (Maloryazanskoye II selishche-russkiy poselok zolotoordynskogo vremeni na Samarskoy Luke // Sredneye Povolzh'ye $\mathrm{v}$ kontekste srednevekovoy rossiyskoy istorii: na perekrestke kul'tur (konets XIII-XVI v.): materialy nauchno-prakticheskoy konferentsii). Samara: Ofort.

Ljungqvist, F. C. (2010). A new reconstruction of temperature variability in the extra-tropical northern hemisphere during the last two millennia. Geografiska Annaler A, 92, 339-351. https:// doi.org/10.1111/j.1468-0459.2010.00399.x.

Matveeva, G. I. (1998). The sites of the Lbische type are the early stage of Imenkov culture. In: Cultures of the Eurasian steppes of the second half of the 1st millennium AD: chronological issues (Pamyatniki lbishchenskogo tipa-ranniy etap imen'kovskoy kul'tury // Kul'tury yevraziyskikh stepey vtoroy poloviny 1 tysyacheletiya n. e.: voprosy khronologii) (pp. 87-97). Samara.

McCormick, M., Büntgen, U., Cane, M., et al. (2012). Climate change during and after the Roman Empire: Reconstructing the past from scientific and historical evidence. Journal of Interdisciplinary History, 43, 169-220.

Novenko, E., Tsyganov, A., Rudenko, O., et al. (2016). Mid- and late-Holocene vegetation history, climate and human impact in the western Mid-Russian Upland: New data and a regional synthesis. Biodiversity and Conservation, 25, 2453-2472.

Novenko, E., \& Volkova, E. M. (2015). The middle and late Holocene vegetation and climate history of the forest-steppe ecotone area in the central part of European Russia. Geographical Review of Japan Series B, 87, 1-8.

Novenko, E., \& Olchev, A. (2015). Early Holocene vegetation and climate dynamics in the central part of the East European Plain (Russia). Quaternary International, 388, 12-22.

Novenko, E., Tsyganov, A., Volkova, E., et al. (2015). The Holocene palaeoenvironmental history of central European Russia reconstructed from pollen, plant macrofossil and testate amoeba analyses of the Klukva peatland, Tula region. Quaternary Research, 83, 459-468. 
Novenko, E., Volkova, E. M., Glasko, M. P., et al. (2011). Palaeoecological evidence for the middle and late Holocene vegetation, climate and land use in the upper Don River basin (Russia). Vegetation History and Archaeobotany, 21, 337-352.

Novenko, E., Glasko, M., \& Burova, O. (2009). Landscape-and-climate dynamics and land use in Late Holocene forest-steppe ecotone of East European Plain (upper Don River Basin case study). Quaternary International, 203, 113-119.

PAGES2k Consortium. (2013). Continental-scale temperature variability during the past two millennia. Nature Geoscience, 6, 339-346. https://doi.org/10.1038/ngeo1797.

Sigl, M., Winstrup, M., McConnell, J., et al. (2015). Timing and climate forcing of volcanic eruptions for the past 2500 years. Nature, 523, 543-549.

Stoffel, M., Khodri, M., Corona, C., et al. (2015). Estimates of volcanic-induced cooling in the Northern Hemisphere over the past 1500 years. Nature Geoscience, 8, 784-788.

Viau, A., Gajewski, K., Sawada, M., et al. (2006). Millennial-scale temperature variations in North America during the Holocene. Journal of Geophysical Research-Atmospheres, 111, D09102. https://doi.org/10.1029/2005jd006031.

\section{In Russian}

Ageev, B. B. (1992). Pyany Bor culture (P'yanoborskaya kul'tura). Ufa: Bashkirskiy nauchnyy tsentr Ural'skogo otdeleniya Rossiyskoy akademii nauk.

Alisov, B. P. (1956). Climate of USSR (Klimat SSSR). Moscow: Moscow University.

Archaeological map of Tatarstan. (1981-1990). (ed. by A.Kh. Khalikov and P.N. Starostin) (Vol. 1-6) (Arkheologicheskaya karta Tatarstana. Toma 1-6). Academiya Nauk SSSR, Kazanskiy filial, Kazan, Moscow.

Archaeological map of the Chuvash Republic. (2013-2015). (E. P. Mikhailov \& N. S. Berezina (Eds.)) (Vol. 1-3) (E. P. Mikhailov \& N. S. Berezina, etc (Eds.)) (Arkheologicheskaya karta Chuvashskoy Respubliki. Avtory-sostaviteli: Ye.P. Mikhaylov, N. S. Berezina i dr.). Chuvashskoye knizhnoe izdatelstvo, Cheboksary.

Bagautdinov, R. S., Bogachev, A. V., \& Zubov, S. E. (1998). Pre-Bulgarians in the Mid-Volga (at the beginnings of the history of the Volga-Kama Tatars (Prabolgary na Srednej Volge: u istokov istorii tatar Volgo-Kam'ya). Samara.

Belavin, A. M. (2000). Kama trade route (Kamskiy torgovyy put') Izdatel'stvo Permskogo peduniversiteta. Perm.

Belorybkin, G. N. (2003). Western part of the Volga region during the Middle Ages (Zapadnoye Povolzh'ye v sredniye veka) Izdatel'stvo PGPU. Penza.

Blagoveshenskaya, N. V. (2009). Dynamics of the vegetation cover of central part of the Volga Upland in the Holocene (Dinamika rastitel'nogo pokrova tsentral'noi chasti Privolzhskoi vozvyshennosti v golotsene). Ul'yanovsk.

Bogachev, A. V. (2000). Antiquities of the nomads of the Hunnic and post-Hunnic time periods (5th-6th centuries CE). In History of the Samara Volga region from the prehistory to the recent time (Vol. 3, pp. 135-154). The Early Iron Age and the Middle Ages (Drevnosti kochevnikov gunnskogo i postgunnskogo vremeni (V-VI veka n.e.) // Istoriya Samarskogo Povolzh'ya s drevneyshikh vremen do nashikh dney. Ranniy zheleznyy vek i srednevekov'ye.). Nauka, Moscow.

Bugrov, D. G. (1998). Sites of the Azelino Culture in the Trans-Kama region. In: Bolgar and the problems of the historical development of the Western part of the Trans-Kama region. 60 years of the archaeological study: the results and the prospects. Abstracts (Pamyatniki azelinskoy kul'tury v Zakam'ye // Bolgar i problemy istoricheskogo razvitiya Zapadnogo Zakam'ya. 60 let arkheologicheskogo izucheniya: itogi i perspektivy. Tezisy nauch. konferentsii) (pp. 18-19). Bolgar.

Bugrov, D. G., Linkina, L. I., Melnikov, L. V., \& Nikolaeva, K. V. (2011). On the issue of land use of the Pyany Bor Culture population (based on the comprehensive study of the Toiguzino 2 hillfort) (K voprosu o zemlepol'zovaniya naseleniya p'yanoborskoj kul'tury (po materialam 
kompleksnogo issledovaniya Tojguzinskogo II gorodishcha // Arkheologiya i estestvennye nauki Tatarstana. Kniga 4). In Archeology and sciences of Tatarstan (Vol. 4, pp. 225-244). Kazan.

Burov, G. M. (1977). Archaeological map of the Ulyanovsk region (Arheologicheskaya karta Ul'yanovskoj oblasti). Simferopol.

Dubman, E. L. (2012). South-West of the European Russia. Part 1. Volga frontier in the mid of 16th-17th cent (Yugo-Vostok Yevropeyskoy Rossii. Chast' I. Povolzhskiy frontir v seredine XVI-XVII vv. Ocherki istorii). Samara, Samarskiy universitet.

Fakhrutdinov, R. G. (1975). Archaeological sites of the Volga-Kama Bulgaria and its territory (Arkheologicheskiye pamyatniki Volzhsko-Kamskoy Bolgarii i yeye territoriya). Kazan: Tatarskoye knizhnoye izdatel'stvo.

Gening, V. F. (1963). Azelino Culture of the 3rd-5th cc. Essays on the History of the Vyatka Krai during the Migration period. Issues of the archeology of the Urals (Vol. 5) (Azelinskaya kul'tura III-V vv. Ocherki istorii Vyatskogo kraya v epokhu pereseleniya narodov // Voprosy arkheologii Urala. Vyp.5). Izhevsk, Sverdlovsk.

Gening, V. F. (1976). The Turaevo necropolis of the 5th century CE (burials of warlords). In From the history in the Volga and Kama regions (Turayevskiy mogil'nik V v. n.e. (zakhoroneniye voyenachal'nikov) // Iz istorii Volgo-Kam'ya). Kazan.

Gening, V. F. (1977). The sites near Kushnarenkovo village on the Belaya River (6th-7th centuries $\mathrm{CE}$ ) // Studies on the archeology of the Southern Urals (Pamyatniki u s. Kushnarenkovo na r. Beloy (VI-VII vv. n. e.) // Issledovaniya po arkheologii Yuzhnogo Urala) (pp. 90-136). Ufa.

Gismatulin, M. R. (2006). A find of the early medieval belt tip in Ulyanovsk. In: Proceedings of the Third Scientific Conference, Dedicated to the Scientist and Local Historian S.L. Sytin (Nakhodka v Ul'yanovske rannesrednevekovogo nakonechnika poyasa // Materialy tret'yey nauchnoy konferentsii, posvyashchonnoy uchonomu i krayevedu S.L. Sytinu)ю Izdatel'stvo "Korporatsiya tekhnologiy prodvizheniya" (pp. 202-206). Ulyanovsk.

Gismatulin, M. R. (2014). Setttlement of Sengiley in the Volga trade route system (Sengileevskoye poseleniye v sisteme Volzhskogo torgovogo puti // Vestnik SamGU. 2014. № 9 (120)). Samara State University herald, 9(120), 73-77.

Goldina, R. D., \& Chernykh, E. M. (2011). Archaeological map of the Karakulinskiy district of the Udmurtian Republic. Contributions and investigations of the Kama-Vyatka archaeological expedition (Vol. 18) (Arkheologicheskaya karta Karakulinskogo rayona Udmurtskoy Respubliki. Materialy i issledovaniya Kamsko-Vyatskoy arkheologicheskoy ekspeditsii. T.18). Izhevsk.

Grishakov, V. V. (2000). On the early stage of the Penza burial grounds. In The Volga Finns and their neighbors during the Middle Ages (Problems of chronology and ethnic history) (O ranney stadii penzenskikh mogil'nikov // Povolzhskiye finny i ikh sosedi v epokhu srednevekov'ya (problemy khronologii i etnicheskoy istorii)) (pp. 8-15). Saransk.

Grishakov, V. V. (2017). The main trends of the genesis of the archaeological cultures in the territory of the Mordovia in the Early Iron Age and during the initial stage of the Migration period (Osnovnyye tendentsii genezisa arkheologicheskikh kul'tur na territorii Mordovskogo kraya v rannem zheleznom veke i na nachal'nom etape velikogo pereseleniya narodov // Istoricheskiye, filosofskiye, politicheskiye i yuridicheskiye nauki, kul'turologiya i iskusstvovedeniye. Voprosy teorii i praktiki.—2017—№ 2 (76)). History, philosophy, politics and law, culturology and art history. Theoretical and Practical Issues, 2(76), 68-74 (Saransk).

History of the Samara Volga region from the prehistory to the recent time. (2000). Vol. 3: The early iron age and the middle ages. Nauka, Moscow.

Ivanov, A. G. (1997). Ethnic and cultural relations of the Cheptsa River valley population during the Middle Ages: From the end of the 5th cent to the first half of the 13th cent (Etnokul'turnyye i ekonomicheskiye svyazi naseleniya basseyna r.Cheptsy v epokhu srednevekov'ya: konets $\mathrm{V}$-pervaya polovina XIII v.). Udmurtskiy institut istorii, yazyka b literatury UrO RAN, Izhevsk.

Izmaylov, I. L. (2006). The establishment of the Bulgarian State. In History of the Tatars from the ancient times. 7 volumes. Volume 2. The Volga Bulgaria and the Great Steppe (Obrazovaniye Bulgarskogo gosudarstva // Istoriya tatar s drevneyshikh vremen. V 7-i tomakh. Tom 2. Volzhskaya Bulgariya i Velikaya Step') (pp. 124-131). RukhIL, Kazan.

Izmaylov, I. L. (2009a). Ulus of Bolgar: Bulgar and other emirates. In History of the Tatars from the ancient times. 7 volumes. Volume 3. Ulus of Jochi (Golden Horde). 13th-mid-15th cc. (Bulgarskiy 
ulus: Bulgar i drugiye emiraty// Istoriya tatar s drevneyshikh vremen. V 7-i tomakh. Tom 3. Tom 3. Ulus Juchi (Zolotaya Orda). XIII-seredina XV vv.) (pp. 448-469). RukhIL, Kazan.

Izmaylov, I. L. (2009b). Ecological disasters. In History of the Tatars from the ancient times. 7 volumes. Volume 3. Ulus of Jochi (Golden Horde). 13th-mid-15th cc. (Ekologicheskiye kataklizmy // Istoriya tatar s drevneyshikh vremen. V 7-i tomakh. Tom 3. Tom 3. Ulus Juchi (Zolotaya Orda). XIII-seredina XV vv.) (pp. 682-686). RukhIL, Kazan.

Journey of Ibn-Fadlan. (2016). Volga Route from Baghdad to Bolgar. Exhibition catalogue (Puteshestvie Ibn Fadlana: Volzhskij put' ot Bagdada do Bolgara. Katalog vystavki). Moscow.

Kazakov, Y. P. (1981). Sites of the Kushnarenkovo culture in the lower Kama region. In On the historical sites in the valleys of the Kama and Belaya rivers (Kushnarenkovskiye pamyatniki Nizhnego Prikam'ya // Ob istoricheskikh pamyatnikakh po dolinam Kamy i Beloy) (pp. 115-135). Kazan.

Kazakov, Y. P. (1992). The culture of the early Volga Bulgaria (Kul'tura ranney Volzhskoy Bolgarii). Nauka, Moscow.

Khalikov, N. A. (2006). Rural economy. Agriculture. In History of Tatars from the ancient times. 7 volumes. Volume 2. The Volga Bulgaria and the Great Steppe (Selskoye khozyaystvo i promysly. Zemledeliye // Istoriya tatar s drevneyshikh vremen. V 7-i tomakh. Tom 2. Volzhskaya Bulgariya i Velikaya Step') (pp. 236-240). RukhIL, Kazan.

Khuzin, F. S. (2006). Bulgarian cities and the issues of their origin. In History of Tatars from the ancient times. 7 volumes. Volume 2. Volga Bulgaria and the Great Steppe (Bulgarskiye goroda i problemy ikh proiskhozhdeniya // Istoriya tatar s drevneyshikh vremen. V 7-i tomakh. Tom 2. Volzhskaya Bulgariya i Velikaya Step') (pp. 152-163). RukhIL, Kazan.

Khuzin, F. S. (2011). On the time of the sedentarisation of the Volga Bulgarians. In Studies on the Bulgaian and Tatarian archeology (O vremeni vozniknoveniya osedlosti u volzhskikh bulgar // Issledovaniya po Bulgaro-Tatarskoy arkheologii) (pp. 29-42). OOO Foliant, Kazan.

Klimanov, V. A., \& Serebraynnaya, T. A. (1986). Changes in the vegetation and climate in the Central Upland during the Holocene (Izmeneniya rastitel'nosti i klimata na Srednerusskoi vozvyshennosti v golotsene). Izvestiya AN SSSR. Seriya Geograficheskaya, 1, 26-37.

Kochkina, A. F. (2016). On the spatial system in the right bank of the Volga in the Samara region during the Golden Horde period. In Dialogue between the urban and the steppe cultures in the Eurasian area. Historical geography of the Golden Horde. Proceedings of the Seventh International Conference in Memory of G.A. Fedorov-Davydov (K kharakteristike prostranstvennoy organizatsii sistemy rasseleniya v pravoberezh'ye Samarskogo Povolzh'ya v zolotoordynskiy period // Dialog gorodskoy i stepnoy kul'tur na Yevraziyskom prostranstve. Istoricheskaya geografiya Zolotoy Ordy» Materialy Sed'moy Mezhdunarodnoy konferentsii, posvyashchonnoy pamyati G. A. Fodorova-Davydova) (166-170). Kazan, Yalta, Chisinau.

Kuz'minykh, S. V., \& Chizhevsky, A. A. (2009). Foreword. At the beginning of the archeology of the Volga and Kama regions (To the 150th anniversary of the discovery of the Ananyino burial ground). Series "Archeology of the Eurasian steppes." (Predisloviye // U istokov arkheologii Volgo-Kam'ya (K 150-letiyu otkrytiya Anan'inskogo mogil'nika). Seriya «Arkheologiya yevraziyskikh stepey». Vyp. 8) (Vol. 8, pp. 4-5). Almedia, Yelabuga.

Leschinskaya, N. A. (2014). Vyatka Krai during the Pyany Bor period (based on the funerary sites of the 1st-5th centuries AD). Contributions and studies of the Kama-Vyatka archaeological expedition (Vyatskiy kray v p'yanoborskuyu epokhu (po materialam pogrebal'nykh pamyatnikov I-V vv. n.e.). Materialy i issledovaniya Kamsko-Vyatskoy arkheologicheskoy ekspeditsii. T.27.) (Vol. 27). Izhevsk.

Mardanshina, E. M. (2008). Tillage implements of Volga Bulgarians in 10th-13th cent AD. On the issue of the agricultural techniques. Ph.D. thesis (Zemledel'cheskiye orudiya volzhskikh bulgar 10-13 vv. (k probleme svoyeobraziya zemledeliya). Kazan.

Matveeva, G. I. (1997). Burial mounds of the Early Bulgarians on Samara Luka (Mogil'niki rannih bolgar na Samarskoj Luke). Samara: Samarskiy Universitet.

Matveeva, G. I. (2000a). The sites of the sedentary tribes of the forest zone of the Samara Volga region (Belaya Gora and Gorodets Cultures). In History of the Samara Volga region from the 
prehistory to the recent time. Vol. 3: The Early Iron Age and the Middle Ages (Pamyatniki osedlykh plemen lesnoy zony Samarskogo Povolzh'ya (belogorskaya i gorodetskaya kul'tury) // Istoriya Samarskogo Povolzh'ya s drevneyshikh vremen do nashikh dney. Ranniy zheleznyy vek i srednevekov'ye) (pp. 82-93). Nauka, Moscow.

Matveeva, G. I. (2000b). The sites of the initial stage of the Migration period (the 2nd-the 4th cent CE). In History of the Samara Volga region from the prehistory to the recent time. Vol. 3: The Early Iron Age and the Middle Ages (Pamyatniki nachala epokhi velikogo pereseleniya narodov (II-IV vv. n.e.) // Istoriya Samarskogo Povolzh'ya s drevnejshih vremen do nashih dnej. Rannij zheleznyj vek i srednevekov'e) (pp. 94-105). Nauka, Moscow.

Matveeva, G. I. (2003). On the question of the Lbische hillfort chronology. In The contact areas of Eurasia on the turn of the epochs (K voprosu o khronologii gorodishcha Lbishche // Kontaktnye zony Evrazii na rubezhe ehpoh) (pp. 90-93). Samara.

Matveeva, G. I. (2004). The Middle Volga region in the 4th-7th centuries: the Imen'kovo culture. Textbook (Srednee Povolzh'e v IV-VII vv.: imen'kov-skaya kul'tura. Uchebnoe posobie). Samara.

Motsya, A. P., Khalikov, A. K. (1997). Bulgar-Kiev. Ways, connections, destinies (Bulgar-Kiyev. Puti, svyazi, sud'by). Institut arkheologii Akademii nauk Ukrainy, Kiev; Akademiya nauk Respubliki Tatarstan, Kazan.

Mukhametshina, A. S. (1999). Kominternovskiy Kurgan. Issues of the interpretation. In Bolgar and studies of the antiquities of the Urals and the Volga regions. To the 100th anniversary of A.P. Smirnov. Abstracts (Kominternovskiy kurgan. Problemy atributsii // Bolgar i problemy izucheniya drevnostey Uralo- Povolzh'ya. 100-letiye A.P. Smirnova. Tezisy nauchnoy konferentsii). BGIAMZ, Bolgar.

Myasnikov, N. S. (2013). Ethno-cultural processes in the Chuvashia part of the Volga region in the 1st-8th centuries $A D$ according the archaeological records. Scientific reports. Issue 13 (Etnokul'turnyye protsessy v Chuvashskom Povolzh'ye v 1- 8 vv n.e v svete arkheologicheskikh dannykh. Nauchnyye doklady CHGIGN. Vyp. 13). ChGIIGN, Cheboksary.

Myshkin, V. N., Skarbovenko, V. A. (2000). Nomads of the Samara Volga region in the early Iron Age. In History of the Samara Volga region from ancient times to the present. Early Iron Age and the Middle Ages (Kochevniki Samarskogo Povolzh'ya v rannem zheleznom veke. // Istoriya Samarskogo Povolzh'ya s drevneyshikh vremen do nashikh dney. Ranniy zheleznyy vek i srednevekov'ye) (pp. 9-82). Moscow.

Nedashkovsky, L. F. (2009). International and internal trade. In History of the Tatars from the ancient times. 7 volumes. Volume 3. Ulus of Jochi (Golden Horde). 13th-mid-15th cc. (Mezhdunarodnaya i vnutrennyaya torgovlya // Istoriya tatar s drevneyshikh vremen. V 7-i tomakh. Tom 3. Tom 3. Ulus Juchi (Zolotaya Orda). XIII-seredina XV vv.) (pp. 277-287). RukhIL, Kazan.

Orudzhov, E. I. (2017). Spatial system of the population of the Ananyino area of cultures in the basins of the rivers Vyatka and Vetluga Rivers (Sistema rasseleniya nositelej anan'inskoj kul'turnoistoricheskoj oblasti v bassejne rek Vyatka i Vetluga // Povolzhskaya arkheologiya. 2017. N 3). Volga River Region Archaeology, 3(21), 117-140.

Ostanina, T. I. (1997). The population of the Middle Kama region in the 3rd-5th centuries (Naselenie Srednego Prikam'ya v III-V vv). Udmurtskiy institut istorii, yazyka i literatury UrO RAN, Izhevsk.

Ostanina, T. I. (2002). Kuziebaevo hillfort of the 4th, 5th and 7th centuries. Catalogue of the archaeological collection (Kuzebaevskoe gorodishche IV-V, VII vv. Katalog arheologicheskoj kollekcii). Izhevsk.

Petrenko, A. G. (2011). Human-nature interactions in the Middle Volga and Cis-Urals in the early Middle Ages. In Archeology and sciences of Tatarstan. Vol. 4. Commemoration of Aida Grigorievna Petrenko, Ph.D. (Vzaimodeystviye cheloveka i prirody na territorii Srednego Povolzh'ya i Predural'ya v epokhu rannego srednevekov'ya // Arkheologiya i yestestvennyye nauki Tatarstana. Kniga 4. Posvyashchayetsya pamyati doktora biologicheskikh nauk Aidy Grigor'yevny Petrenko) (pp. 17-43). Sh. Marjani Institute of History of the Academy of Sciences of the Republic of Tatarstan, Kazan. 
Petrenko, A. G. (2009). Co-influence of climatic and anthropogenic factors on the economy of the population of the Middle Volga and Cis-Urals in the Late Bronze Age-Early Iron Age. In At the beginning of the archeology of the Volga and Kama regions (To the 150th anniversary of the discovery of the Ananyino burial ground). Series "Archeology of the Eurasian steppes." (Vol. 8) (Vzaimovliyaniye prirodno-klimaticheskikh i antropogennykh faktorov na izmeneniye tipov vedeniya khozyaystva $\mathrm{v}$ epokhu pozdney bronzy-rannego zheleza u naseleniya Srednego Povolzh'ya i Predural'ya // U istokov arkheologii Volgo-Kam'ya (k 150-letiyu otkrytiya Anan'inskogo mogil'nika)) (pp. 160-169). Almedia, Elabuga.

Petrenko, A. G. (2006). Rural economy. Animal breeding. In History of Tatars from the ancient times. 7 volumes. Volume 2. The Volga Bulgaria and the Great Steppe (Selskoye khozyaystvo i promysly. Zhivotnovodstvo // Istoriya tatar s drevneyshikh vremen. V 7-i tomakh. Tom 2. Volzhskaya Bulgariya i Velikaya Step') (pp. 240-246). RukhIL, Kazan.

Polivanov, V. N. (1890). A note on the origin of a copper vessel from the Sengileevsky Uyezd of the Simbirsk province. In Proceedings of the Seventh Archaeological Congress in Yaroslavl, 1887 (Vol. 1, p. 39) (Zametka o proiskhozhdenii mednogo sosuda iz Sengileyevskogo uyezda Simbirskoy gubernii // Trudy sed'mogo arkheologicheskogo s"yezda v Yaroslavle, 1887. Tom 1). Moscow.

Poluboyarinova, M. D. (2006). The road from Bulgar to Kiev. Trade relations with Kievan Rus' and the Old-Russian principalities. In History of the Tatars from ancient times. 7 volumes. Volume 2. Volga Bulgaria and the Great Steppe (Put' iz Bulgara v Kiyev. Torgovyye svyazi s Kiyevskoy Rus'yu i drevnerusskimi knyazhestvami // Istoriya tatar s drevneyshikh vremen. V 7-i tomakh. Tom 2. Volzhskaya Bulgariya i Velikaya Step') (pp. 316-326). RukhIL, Kazan.

Ponomarenko, E. V., Ponomarenko, D. S., Stashenkov, D. A., \& Kochkina, A. F. (2015). Approaches to reconstructing patterns of human occupation from soil features and charcoal (Podkhody $\mathrm{k}$ rekonstruktsii dinamiki zaseleniya territorii po pochvennym priznakam // Povolzhskaya arkheologiya. №1. 2015.) Volga River Regional Archaeology, 1(11), 126-160.

Rudenko, K. A. (2016). Bulgarian Ulus of the Golden Horde: Historical geography. In Dialogue between the urban and the steppe cultures in the Eurasian area. Historical geography of the Golden Horde. Proceedings of the Seventh International Conference in Memory of G.A. FedorovDavydov (Bulgarskiy ulus Zolotoy Ordy: istoricheskaya geografiya // Dialog gorodskoy i stepnoy kul'tur na Yevraziyskom prostranstve. Istoricheskaya geografiya Zolotoy Ordy» Materialy Sed'moy Mezhdunarodnoy konferentsii, posvyashchonnoy pamyati G. A. Fodorova-Davydova) (pp. 131-134). Kazan, Yalta, Chisinau.

Rudenko, K. A. (2013). Nomads in the Ulus of Bulgar of the Golden Horde (according to archeology) (Kochevniki v Bulgarskom Uluse Zolotoy Ordy (po dannym arkheologii) // Povolzhskaya arkheologiya №2 (4)). Volga River Region Archaeology, 2(4), 189-211.

Semykin, Y. A. (1996). On the issue of the early Bulgarian settlements in the Middle Volga region. In Cultures of the Eurasian steppes of the second half of the 1st millennium CE. Proceedings of the International Archaeological Conference. November 14-17, 1995 (K voprosu o poseleniyakh rannikh bolgar v Srednem Povolzh'ye // Kul'tury yevraziyskikh stepey vtoroy poloviny I tysyacheletiya n.e. Materialy Mezhdunarodnoy arkheologicheskoy konferentsii. 14-17 noyabrya 1995 g. Samara. Samarskiy oblastnoy istoriko-krayevedcheskiy muzey im. P.V.Alabina, Samara) (pp. 66-83). Samara: Alabin Samara Regional Museum of Local Lore.

Semykin, Y. A., \& Matveeva, G. I. (2010). Land use and economy of the early medieval population of the Novaya Sloboda archaeological ensamble in the Sengileevsky district of the Ulyanovsk Region. In Notes on the local studies of the Alabin Samara Regional Local Lore Museum. Vol. 15. 40 years of the Middle Volga archaeological expedition (Osvoyeniye prirodnykh resursov, stanovleniye i razvitiye khozyaystva u rannesrednevekovogo naseleniya Novoslobodskoy gruppy pamyatnikov v Sengileyevskom rayone Ul'yanovskoy oblasti // Kraevedcheskie zapiski SOIKM imeni P.V. Alabina. Vol. 15. 40 let Srednevolzhskoj arheologicheskoj ehkspedicii) (pp. 243-255). Samara.

Serebryannaya, T. A. (1976). Forest-steppe interactions in the Central Russian Upland in the Holocene (according paleobotanical and radiocarbon data) (Vzaimootnosheniya lesa i stepi na Srednerusskoy vozvyshennosti v golocene (po paleobotanicheskim i radiouglerodnym dannym). Istoriya biogeozenosov SSSR v golotsene) (pp. 159-166). Nauka, Moscow. 
Shamiloglu, U. (2009). The Black Death and its consequences. In History of the Tatars from ancient Times. 7 volumes. Volume 3. Ulus of Jochi (The Golden Horde). 8th-15th centuries (Chernaya smert' i yeyo posledstviya // Istoriya tatar s drevneyshikh vremen. V 7-i tomakh. Tom 3. Tom 3. Ulus Juchi (Zolotaya Orda). XIII-seredina XV vv.) (pp. 686-691). RukhIL, Kazan.

Sitdikov, A. G. (2016). Historical geography of the Middle Volga region: The second half of the 14th-First half of the 15th century. In Dialogue between the urban and the steppe cultures in the Eurasian area. Historical geography of the Golden Horde. Proceedings of the Seventh International Conference in Memory of G.A. Fedorov-Davydov (Istoricheskaya geografiya Srednego Povolzh'ya: vtoraya polovina XIV—pervaya polovina XV v. // Dialog gorodskoy i stepnoy kul'tur na Yevraziyskom prostranstve. Istoricheskaya geografiya Zolotoy Ordy» Materialy Sed'moy Mezhdunarodnoy konferentsii, posvyashchonnoy pamyati G. A. Fyodorova-Davydova) (pp. 135-141). Kazan; Yalta; Chisinau.

Spiridonova, E. A. (1991). The evolution of the vegetation cover of Don basin in the Upper Pleistocene and Holocene (Evolyutsiya rastitel'nogo pokrova basseina Dona v verkhnem pleistotsene-golotsene). Moscow.

Stashenkov, D. A. (2003). Tsaryov Kurgan. Catalogue of the archaeological collection (Tsarev kurgan. Katalog arkheologicheskoy kollektsii). Samara.

Stashenkov, D. A. (2016). Kuz'kinsky burial ground of the Mordovian people of the end of the 13th-14th century: New data on the population of the Samara Volga region in the Golden Horde period. In Dialogue between urban and steppe cultures in the Eurasian space. Historical geography of the Golden Horde. Materials of the Seventh International Conference dedicated to the memory of GA Fedorov-Davydov (Kuz'kinskiy mordovskiy mogil'nik kontsa XIII-XIV v.: novyye materialy o naselenii Samarskogo Povolzh'ya v epokhu Zolotoy Ordy // Dialog gorodskoy i stepnoy kul'tur na Yevraziyskom prostranstve. Istoricheskaya geografiya Zolotoy Ordy. Materialy Sed'moy Mezhdunarodnoy konferentsii, posvyashchonnoy pamyati G. A. FodorovaDavydova) (pp. 201-204). Kazan, Yalta, Chisinau.

Stashenkov, D. A. (2010a). On the chronological correlation between the Lbische type and the early sites of the Imen'kovo Culture (O hronologicheskom sootnoshenii pamyatnikov lbishchenskogo tipa i rannih pamyatnikov imen'kovskoj kul'tury. Izvestiya Samarskogo nauchnogo centra Rossijskoj akademii nauk. Vol. 12. № 6-1). Announcements of the Samara Scientific Center of the Russian Academy of Sciences, 12(6-1), 272-275.

Stashenkov, D. A. (2010b). On the early date of the Imen'kovo Culture. In Notes on the local studies of the Alabin Samara Regional Local Lore Museum. Vol. 15. 40 years of the Middle Volga archaeological expedition (O rannej date imen'kovskoj kul'tury // Kraevedcheskie zapiski SOIKM imeni P.V. Alabina. Vol. 15. 40 let Srednevolzhskoj arheologicheskoj ehkspedicii) (pp. 118-120). Samara.

Stashenkov, D. A. (2010c). On the groups of settlements of the Khazar period in the Samara and Simbirsk part of the Volga region. In Cultures of the Eurasian steppes of the second half of the 1st millennium $A D$ (issues of interethnic contacts and intercultural interaction) (O gruppakh poseleniy khazarskoy epokhi v Samaro-Simbirskom Povolzh'ye // Kul'tury yevraziyskikh stepey vtoroy poloviny I tysyacheletiya n.e. (voprosy mezhetnicheskikh kontaktov i mezhkul'turnogo vzaimodeystviya)) (pp. 118-127). Ofort, Samara.

Stashenkov, D. A. (2007). Ethno-cultural landscape of the Samara Volga region at the beginning of the Migration period. In Medieval archeology of the Eurasian steppes. Proceedings of the Constituent Meeting of the International Congress. Vol. I (Etnokul'turnaya situatsiya v Samarskom Povolzh'ye v nachale epokhi Velikogo Pereseleniya narodov // Srednevekovaya arkheologiya yevraziyskikh stepey. Materialy Uchreditel'nogo s"yezda Mezhdunarodnogo kongressa. T. I) (pp. 75-81). Institute of History of the Academy of Sciences of the Republic of Tatarstan. Kazan.

Stashenkov, D. A. (2005). The sedentary population of the Samara Volga region forest-steppe in the 1st-5th centuries AD. Series "The Early Slavic world". Issue 7 (Osedloe naselenie Samarskogo lesostepnogo Povolzh'ya v I-V vekah n.eh. Seriya "Ranneslavyanskiy mir". Vypusk 7). Nauka, Moscow. 
Valeev, R. M. (2010). Trade between Volga Bulgaria and northern and western Europe in the preMongolian period (9th-early 13th century) (Torgovlya Volzhskoy Bulgarii i severnoy i zapadnoy Yevropoy v domongol'skiy period (9-nachalo 13 veka) // Vestnik Novosibirskogo gosudarstvennogo universiteta. Seriya: Istoriya. Filologiya. T. 10.-Vyp. 3). Bulletin of Novosibirsk State University. Series: History. Philology, 10(3), 175-182.

Vasil'yev, D. V. (2015). The city and the region of Saksin according to the new archaeological data (Gorod i oblast’ Saksin v svete novykh dannykh arkheologii // Povolzhskaya arkheologiya. №2 (12)). Volga River Region Archaeology, 2(12), 189-267.

Viskalin, A. V. (1992). Samara version of the Volga river crossing on the Bolgar-Kiev route. In The road from Bolgar to Kiev (Samarskiy variant perepravy cherez Volgu na puti iz Kiyeva v Bulgar // Put' iz Bulgara v Kiyev) (pp. 40-46). Institut yazyka, literatury i istorii im. G. Ibragimova, Kazan.

Volkova, E. V. (2017). Manchikha hillfort-The Early Iron Age site on Samara Luka. In The Bronze Age and the early Iron Age. Proceedings of the 3rd International Conference "The Ananyino World: The Cultural Space, Networks, Traditions, and Innovations'. Cultures of the Eurasian Steppes. Issue 4 (Gorodishche manchikha—pamyatnik zheleznogo veka na Samarskoy Luke epokha bronzy i ranniy zheleznyy vek. Materialy III mezhdunarodnoy nauchnoy konferentsii «Anan'inskiy mir: kul'turnoye prostranstvo, svyazi, traditsii i novatsii» Arkheologiya yevraziyskikh stepey. № 4) (pp. 7-16). Kazan.

Vyazov, L. A. (2007). Spatial system of the Imen'kovo Culture tribes in the underhill part of Samara Luka // Samara region in the history of Russia. Vol. 3. Materials of the interregional scientific conference dedicated to the 120th anniversary of the foundation of the Samara Regional Museum of Local History. P.V. Alabina Samara, December 15-16, 2006 (Sistema rasseleniya plemen imen'kovskoy kul'tury v podgornoy chasti Samarskoy Luki // Samarskiy kray v istorii Rossii. Vyp. 3. Materialy mezhregional'noy nauchnoy konferentsii, posvyashchennoy 120-letiyu so dnya osnovaniya Samarskogo oblastnogo istoriko-krayevedcheskogo muzeya im. P.V. Alabina Samara, 15-16 dekabrya 2006 g.) (pp. 55-69) Samara.

Vyazov, L. A. (2008). On the origins of the Imen'kovo Culture tillage tools. In: Actual issues of the Volga and Urals regions ( Proishozhdenie pahotnyh orudiy imen'kovskoy kultury // Aktualnyie voprosyi arheologii Urala i Povolzhya) (pp. 320-342). Samara.

Vyazov, L. A. (2012). On the origins of the Imen'kovo Culture axes. In Actual issuess of the Volga region archeology (O proiskhozhdenii toporov imen'kovskoy kul'tury // Aktual'nyye voprosy arkheologii Povolzh’ya) (pp. 43-53). Kazan.

Vyazov, L. A., Grishakov, V. V., \& Myasnikov, N. S. (2016). The features of the ceramic complexes from the sites of the Migration period in the Middle Sura region (Osobennosti keramicheskikh kompleksov pamyatnikov Srednego Posur'ya epokhi Velikogo pereseleniya narodov // Voyadzher: mir i chelovek: teoreticheskiy i nauchno-metodicheskiy zhurnal. № 6) (pp. 66-111). Voyager: the World and Man: A Theoretical and Scientific Methodological Journal, 6, Samara State Technical University.

Vyazov, L. A., \& Semykin, Y. A. (2016). Hillfort and settlement Novaya Beden'ga: The Migration period in Ulyanovsk Cis-Volga region. Series "Archaeology of Simbirsk-Ulyanovsk region" (Vol. 1) (Gorodishche i selishche Novaya Beden'ga: epokha Velikogo pereseleniya narodov v Ul'yanovskom Predvolzh'ye. Seriya «Arkheologiya Simbirskogo-Ul'yanovskogo Povolzh'ya» . Vypusk 1). Ulyanovsk: Karamzin Research Institute of History and Culture.

Yavorskaya, L. V., \& Antipina, E. E. (2016). The geography and subsistence of Golden Horde cities as reconstructed from the archaeo-osteological data. In The dialogue between the urban and steppe cultures in the Eurasian space (Geografiya i osobennosti zhizneobespecheniya gorodov Zolotoy Ordy po arkheozoologicheskim dannym // Dialog gorodskoy i stepnoy kul'tur na Yevraziyskom prostranstve. Istoricheskaya geografiya Zolotoy Ordy. Materialy Sed'moy Mezhdunarodnoy konferentsii, posvyashchonnoy pamyati G. A. Fodorova-Davydova) (pp. 204-207). Kazan, Yalta, Chisinau. 
Yemanov, A. G. (1995). North and south in the history of commerce: On the data from Kafa of the 13th-15th centuries (Sever i yug v istorii kommertsii: na materialakh Kafy XIII-XV vv). Tyumen: Rutra.

Zasetskaya, I. P. (1994). The culture of the Southern Russian steppes in the Hun time period (the end of the 4th-the 5th cent) [Kul'tura kochevnikov yuzhnorusskikh stepey v gunnskuyu epokhu (konets IV—V vv.)]. Ellips, Saint-Petersburg.

Zasetskaya, I. P., Kazanskiy, M. M., Ahmedov, I. R., \& Minasyan, R. S. (2007). Morskoj Chulek. The elite burials in the Azov lowlands and the significance in the history of North Black Sea tribes during the post-Huns epoch (Morskoj Chulek. Pogrebeniya znati iz Priazov'ya i ih mesto v istorii plemyon Severnogo Prichernomor'ya v postgunnskuyu ehpohu. Izdatel'stvo Gos. Ehrmitazha, Saint-Petersburg.

Open Access This chapter is licensed under the terms of the Creative Commons Attribution 4.0 International License (http://creativecommons.org/licenses/by/4.0/), which permits use, sharing, adaptation, distribution and reproduction in any medium or format, as long as you give appropriate credit to the original author(s) and the source, provide a link to the Creative Commons license and indicate if changes were made.

The images or other third party material in this chapter are included in the chapter's Creative Commons license, unless indicated otherwise in a credit line to the material. If material is not included in the chapter's Creative Commons license and your intended use is not permitted by statutory regulation or exceeds the permitted use, you will need to obtain permission directly from the copyright holder.

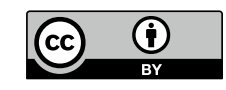

